\title{
Proclus' Reception in Maximus the Confessor, Mediated through John Philoponus and Dionysius the Ps.-Areopagite: A Case Study of Ambiguum 7
}

\author{
Jonathan Greig \\ Austrian Academy of the Sciences, Vienna
}

The early Byzantine Church Father, St. Maximus the Confessor $(\sim 580-$ 662 A.D.), has finally begun to receive the attention that is due him in scholarship on the history of philosophy, ${ }^{1}$ yet much work still remains. Maximus is most well-known for his defense of the theological position that Christ possessed two faculties of will, divine and human, against the Monothelite position that Christ had only one will. ${ }^{2}$ Maximus has also been recognized as a uniquely original thinker and synthesizer, inasmuch as he inherits and transforms the thought of his theological predecessors, especially the Cappadocian Fathers (like St. Gregory of Nyssa and St. Gregory Nazianzen), as well as his philosophical influences in Aristotelian and Platonist thought. In this last respect, Carlos Steel is right to point out Maximus as the "last great representative of the Platonic tradition in Late Antiquity", 3 especially where Maximus appropriates that tradition to articulate a Christian vision of the relation between the created world and the one, Trinitarian God as creator. ${ }^{4}$

With this in mind, in this article I wish to consider the specific heritage of Proclus in Maximus' thought with respect to the "doctrine of the logoi" from Ambiguum 7. Although he discusses this framework in other places beyond this

1 Among others, see most recently Steel, Bart, Van Deun 2018, as well as Bradshaw 2010, Mueller-Jourdan 2005, Steel 2012, Steel 2014, as well as Gersh 1978. Specifically on Proclus' reception in Maximus, see Lauritzen 2012, Mueller-Jourdan 2015b, Petroff 2015 (esp. p. 100, 104-108), and Greig 2017.

2 For an overview of Maximus' life and work, see the introduction of Louth 1996.

3 Steel 2012, p. 229.

4 Cf. Steel, Bart, Van Deun 2018, p. 2276: "Mit seiner Lehre von den Logoi steht Maximos in einer mit Philon einsetzen den und von Origenes fortgeführten langen Tradition, in der die platonische Ideenlehre zur Erklärung des Verhältnisses zwischen den geschaffenen Lebewesen und dem Schöpfer herangezogen wird". 
treatise ${ }^{5}$ Maximus gives a focused discussion in Ambiguum 7 on the logoii.e. 'reasons' or 'reason-principles' 6 - according to which God creates the world, and through which creatures, in turn, participate in God. For Maximus the logoi do not function merely as distinct 'thoughts' in the mind of God, but they also become identified with the one Logos - i.e. the second person of the Trinity: under this conception God is both directly participated and, yet as first cause of all created beings, transcendent and unparticipated.

As has been well-established, Maximus' notion of the logoi draws on multiple sources, both Scriptural and philosophical: already one sees direct Scriptural influence in Maximus from John 1 (esp.1:1-3), where the Logos is identified with God and as that by which (or rather, by whom) all things are created. ${ }^{7}$ One can also see Maximus' philosophical articulation of this Scriptural background both in his appropriation of previous Patristic sources and especially philosophical sources such as Philo of Alexandria, with the latter's understanding of the Logos as both identified with, and distinct from, God, ${ }^{8}$ and Origen's understanding of the Logos as a created principle by God who contains the logoi of all beings. ${ }^{9}$ While much scholarship has already uncovered these latter philosophical influences as well as Maximus' general Neoplatonic influences, ${ }^{10}$ little has yet been done to consider and analyze the specific heritage of Proclus in Maximus' framework of the logoi.

In this article I wish to show how two aspects of Proclus' framework find their way into Maximus' own framework: in particular, Proclus' understand-

See e.g. Maximus the Confessor, Ambiguum 22 (PG 91: 1256D ff.) and Ambiguum 42, 15,116,12 (PG 91: 1329A-D).

6 In the context of Maximus in Ambiguum 7, I will generally leave the term logos untranslated, reflecting his distinct use of the term, as we will discuss it below. In other contexts, like in Philoponus or Proclus (below), I generally translate as 'principles' or 'reasons', depending on context, esp. where, e.g. in Philoponus, logos / logoi are taken analogous to Platonist paradigmatic Forms, not just discursive 'reasons', as the term would more properly indicate in Proclus.

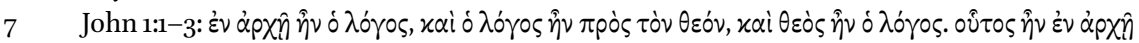

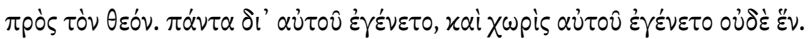

8 Cf. discussion in Boys-Stones 2017, p. 147-183 (esp. p. 158-159), on Philo in the general context of Middle Platonists on the creator god and its relation to the Forms.

9 For a general overview of Maximus' sources on the logoi, especially in Philo, Origen, and Patristic sources, see Bradshaw 2013.

10 Cf. e.g. Louth 2017. See also Wood 2018, which attempts to argue, if somewhat tendentiously, against a quasi-Neoplatonic or Proclean interpretation of Maximus' logoi as 'divine ideas', and instead for a 'Stoic' interpretation, with the logoi as the Logos' immanent 'incarnation' in creation (p. 85). Most of Wood's analysis however does not address a number of points specific to Proclus, discussed below-for instance, the henads as principles of individuality—which are relevant to Maximus' understanding of the logoi. 
ing of the henads as mediators of the unparticipated first cause, the One; ${ }^{11}$

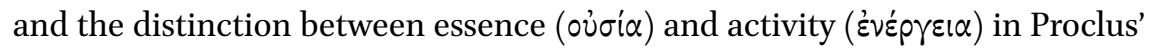
understanding of Soul as pre-containing the logoi of all physical beings in the world. ${ }^{12}$ Although it is not clear to what degree Maximus may have read Proclus directly, ${ }^{13}$ we certainly find Proclus' thought for these two prior aspects conveyed through Maximus' reception of John Philoponus ${ }^{14}$ and Dionysius the Ps.-Areopagite, ${ }^{15}$ where both certainly possessed direct knowledge of Proclus. In Philoponus' case, Proclus' notion of Soul as distinguished between its ovं $\sigma^{\prime} \alpha$

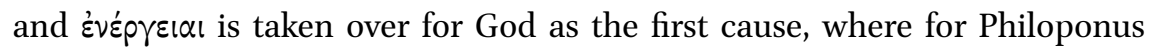
God eternally possesses the logoi of all created beings, yet God's actual willed production of those beings involves a distinct operation which takes place in time. In Dionysius' case, Proclus' understanding of the One and the henads is taken over to explain the simultaneity of God's transcendence, as unparticipated in Himself, and the plurality of participated powers, or 'processions'

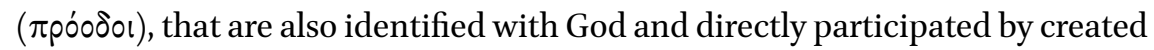
beings. ${ }^{16}$

Maximus thus synthesizes both Philoponus' and Dionysius' reception of Proclus in a distinctly original way-one in which both accounts are ultimately necessary for Maximus' framework. Philoponus' distinction between God's possession of the logoi and God's activity in time, based on the logoi, is essential to address the danger of the Origenist alternative of creatures' co-eternity with God. Yet one difficulty in Philoponus' account is his ability to distinguish in a sufficient way God's being, or possession of the logoi, and God's distinct activity of willing created beings in time. Here Dionysius' dis-

\footnotetext{
11 Proclus, The Elements of Theology, Prop. 113-118.

12 Proclus, The Elements of Theology, Prop. 191, 195.

13 Although cf. above, n. 1.

14 The study of Philoponus' reception and influence in Maximus is woefully lacking in Anglophone scholarship, especially where Maximus' use of Philoponus is crucial to understand Maximus' theory of created being and time / eternity. On current studies of Philoponus in Maximus, see Benevich 2011 (esp. p. 123-124, where Benevich distinguishes Philoponus and Maximus on the logoi), Shchukin 2017, and Varlamova 2017, and briefly in Tollefsen 2012, p. 119-121.

15 On Dionysius' reception in Maximus, among others, see Louth 2008a and Louth 2008b.

16 See M. Vlad's contribution in this volume (p. 9o) on difficulties in Proclus' framework for the One and the henads, in their relation to Being, and Dionysius' reconciliation of these aporiai by collapsing the distinction between the One and the henads. Although touching on this, in this paper I will focus more on the preservation of henadic distinction within Dionysius' transformation of Proclus in the former's notion of the divine 'processions' (זpóodol).
} 
tinction between God as unparticipated and participated becomes necessary for Maximus to refine Philoponus' distinction for God and the logoi in a way that sufficiently addresses God's transcendence 'through Himself' ( $\delta$ ' $\varepsilon \alpha v \tau o ̀ v)$ and God's manifestation in the logo $i$ as distinct principles of creation-both existing prior to time, yet distinguished by their respective relation to created beings. Thus, while respecting the plurality of other sources behind Maximus' understanding of the logoi, as especially in Origen and Philo above, one finds a unique reception of Proclus in Maximus' articulation of God's being in relation to creatures.

\section{The Background to Ambiguum 7: An Origenist Mis-Reading of the Relation between God and Created Being}

Before we analyze Maximus on the logoi and the influences in Proclus, we should first consider the context of Maximus' treatise, Ambiguum 7, in which he establishes his framework: namely a problematic interpretation of the cause of creation. As has been recognized in the scholarship, one of Maximus' main concerns in these passages is to counter an Origenist interpretation of St. Gregory Nazianze in the latter's Orationes 14, according to which human souls have their pre-existence in God. In the passage St. Gregory speaks of humans as

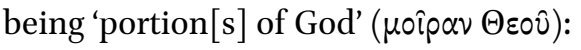

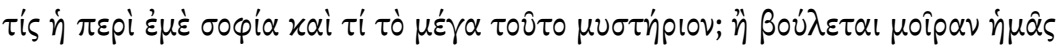

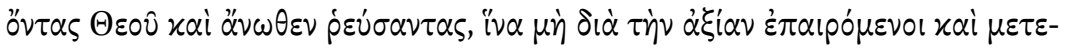

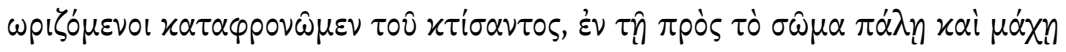

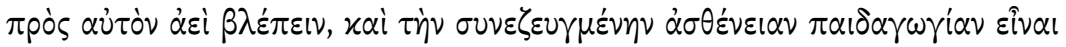
$\tau \circ \hat{\alpha} \dot{\alpha}$ เ $\omega \mu \alpha \tau \circ$;

What is the wisdom that concerns me, and what is this great mystery? Is it that [God] wills that we, being a portion of God and having flowed ( $\rho \varepsilon v \sigma \alpha \nu \tau \alpha \varsigma)$ down from above, always look towards him in the struggle and fight with the body, and [thus] wills that our weakness, having been conjoined with our dignity, be an education, in order that we may not be disdainful of the creator, despite being exalted and lifted up through our dignity ${ }^{17}$

St. GRegory nazianzen, De Pauperum Amore (Orationes 14,7), PG 35: 865,31-37

All translations are my own unless otherwise noted. 
Commenting on this passage, Maximus glosses over the position of 'certain

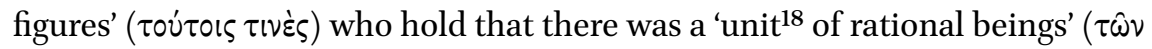
$\lambda \circ \gamma(x \omega \hat{\omega} \nu v \alpha \dot{\delta} \alpha)$ connatural with God before 'movement' ( $\left.\chi^{i} \nu \eta \sigma v\right)$ came about, and out of which those rational beings were dispersed and bound into bodies by God at creation as a punishment for past sins. ${ }^{19}$ Maximus fits these moments into the triad of 'remaining' ( $\mu$ ovn) (for the 'unit' of beings), 'movement' (xivn$\sigma / \zeta)$ (for the motion of those beings from that unit, i.e. God), and 'generation'

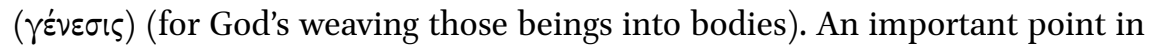
Maximus' reading is that each soul is numerically the same throughout the process: the souls of all embodied humans are ultimately explained in terms of this triadic process. A second corollary to this is that the soul is then eternal by its nature, on Maximus' reading, since it had its existence in this 'unit' together with God, prior to its embodiment.

As has been well-documented by Polycarp Sherwood, Maximus is implicitly addressing an Origenist interpretation of the soul and its coming to be in creation from God, although it is not clear if Maximus has Origen himself or other Origenists in mind. ${ }^{20}$ In either case, although Origenism may be the direct target for Maximus, other scholars like Stephen Gersh hold that Maximus has a more overarching critique (and correction) in mind ${ }^{21}$ —one that also addresses

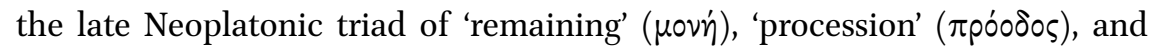

18 In order to differentiate the $\dot{\varepsilon} v \alpha$ s of Proclus from that of Maximus, I translate the term as 'unit' here and reserve 'henad' for Proclus' corresponding principles.

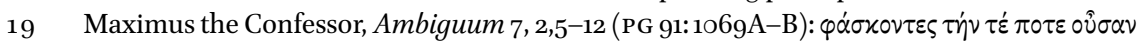

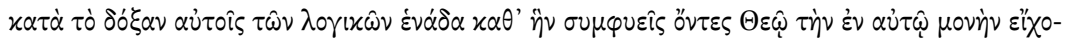

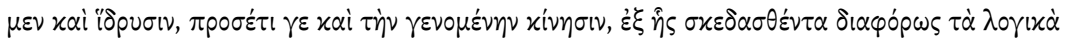

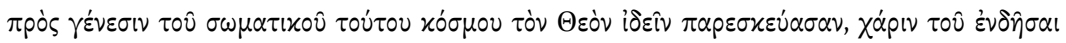

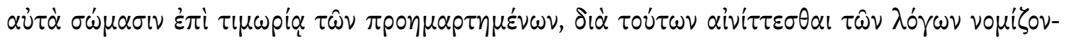

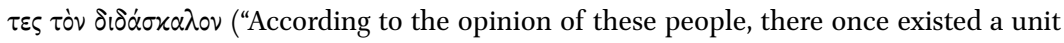
( $\dot{\varepsilon} \alpha \dot{\delta} \delta \alpha)$ of rational beings, by virtue of which we were connatural with God, in whom we had our remaining and abode. In addition to this they speak of a movement that came about, as a result of which the rational beings were variously dispersed, prompting God to look toward the creation of this corporeal world, so that He could bind them in bodies as a punishment for their former sins. This is what they think our teacher Gregory is alluding to in this passage" - trans. Constas, modified).

20 See Sherwood 1955, p. 72-92 for a thorough discussion of the possible sources of Maximus' critique in Ambiguum 7 and 15.

21 See Gersh 1978, p. 219-220, esp. n. 65: "It is now generally accepted that Maximus is attacking the Origenistic doctrine of the primal henad. However, the implications of this critique go even wider than this, for the elements in the Origenistic cosmology which Maximus is keen to refute are precisely those which also characterize traditional pagan Neoplatonism." 


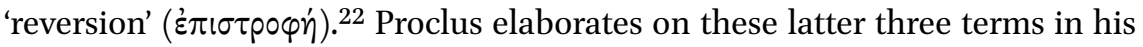
Elements of Theology, Prop. $35^{23}$ where they indicate the different stages of causality between the effect and the cause. 'Remaining' ( $\mu$ ov') thus indicates the effect's source in the cause, insofar as causes pre-contain their effect to a greater degree. ${ }^{24}$ 'Procession' ( $\pi$ póodos) indicates the effect's distinction from the cause. And 'reversion' ( $\dot{\pi} \iota \sigma \tau \rho \dot{\varphi} \varphi \eta)$ indicates the effect's desire for, and/or its fulfillment in, its producer-implicitly its final cause and end, which coincides with the cause. ${ }^{25}$ For Proclus the triad indicates how there can be both continuity between causes and effects as well as simultaneous distinction between both among the hierarchy of immaterial causes, from the first cause (i.e. the

22 Cf. Cvetković 2015 and Constas 2017, which both show that Maximus has a distinct, if solely Christian understanding of the triadic terms in contrast to a Neoplatonic framework. However an important proviso is necessary: Constas (p. 9) appears to say that the third stage, $\dot{\varepsilon} \pi \iota \tau p \circ \varphi \eta$ ', simply implies a straightforward 'return' to the cause for late Neoplatonists in his description of Maximus' third stage as direct contrast: 'Rational creatures, and through them the entire created order, were now seen in terms of their final goal, which was no longer understood as a mere return to the beginning, but rather as an ontologically unprecedented union with God in a final, eschatological, and divinizing consummation.'

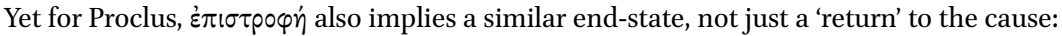
'reversion' can only be understood in the effect's state as having already proceeded-a significant reason why, for example, the soul for Proclus is permanently descended and cannot completely re-ascend to its source in Intellect (see The Elements of Theology, Prop. 211; cf. Steel 1978, esp. p. 23-73, for a history of the notion of the soul as undescended (in Plotinus) vs. descended (in Iamblichus and Proclus)). In this respect Maximus' idea of

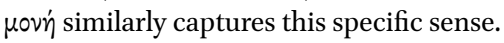

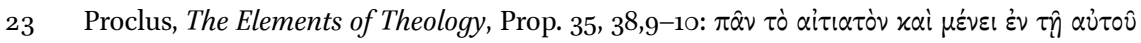

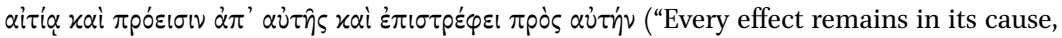
proceeds from it, and reverts towards it"). One should note that Proclus' proof in the Elements is by way of an implicit reductio: Proclus' definition of the necessity of effects to remain in, proceed from, and revert toward their causes is by way of showing that the process cannot be otherwise - that is one cannot have procession without remaining and reversion; remaining without procession and reversion; etc. As Dodds rightly notes in his commentary (ed. Dodds 1963, p. 220-221), Proclus is not original in this three-fold scheme, but instead elucidates a framework already held by earlier Neoplatonists going back to Plotinus-e.g. the relation between the One (as 'remaining'), the One's generation of 'intelligible matter' (as 'procession'), and the turning back of intelligible matter to its source (as 'reversion') — and in doing so, turning to itself and thinking itself as Intellect.

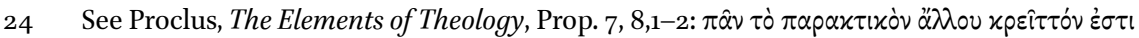

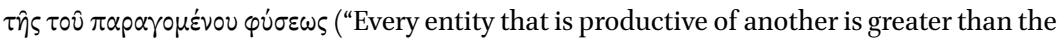
nature of the produced"). For discussion of the history behind this proposition, and its legacy in the later philosophical tradition, see Lloyd 1976.

25 For a discussion of Proclus on triadic causality, including the tension implicit in the notion of entities proceeding from, and simultaneously remaining in, their causes, see the study of Gersh 1973 as well as Dillon 1997 (from the perspective of Damascius). 
One) to physical bodies: for example, Soul and all particular souls derive their being from Intellect, yet since they proceed from Intellect—and in turn revert upon it - they will always be distinct from their cause and, in this sense, can never be assimilated back to it in their essence (ovं $\left.\sigma^{\prime} \alpha\right) \cdot{ }^{26}$

It is not clear if Maximus has this specific framework in mind, or a faulty interpretation of this, when he cites the 'doctrines of the Greeks' ( $\dot{\varepsilon} \kappa \tau \omega \mathrm{\omega} v$ 'E $\mathrm{\lambda} \lambda \eta$ $v(x \hat{\omega} v \delta \circ \gamma \mu \dot{\alpha} \tau \omega \nu)$ as the source for the position he describes above. What is clear, however, is that Maximus wishes to critique a variation of the framework adopted by Origenists that does not account for the created nature of beings - in a way that denies any possibility that they could, in themselves, possess an eternal existence. We see this when Maximus presents the abovementioned position involving the stages of 'remaining', 'motion', and 'generation', and shows the absurdity of the order of this process: a being that is 'remaining' or at rest cannot come into motion if it exists already in actuality, since motion implies an entity being brought from potentiality to actuality or perfection. ${ }^{27}$ Instead for Maximus, all beings exist by their nature in motion-nothing which has come to be is without motion by its nature. ${ }^{28}$ Thus if 'remaining' implies an entity's perfection or actuality, it would not make sense to speak of that entity proceeding from perfection to imperfection, as the progression from 'remaining' to 'motion' might imply. By this reasoning, one cannot speak of creatures pre-existing together with God in their realized state of rest or perfection, but instead this stage can only be realized once creatures have completed their motion. Maximus thus flips the first and third terms of the triad he initially described: from (1) 'rest', (2) 'motion', and (3) 'generation' into (1) 'generation', (2) 'motion', and (3) 'rest'.

In one respect, Maximus' framework seems to be reconcilable with Proclus' own: stages (2) and (3) appear to correspond with Proclus' stages of 'proces-

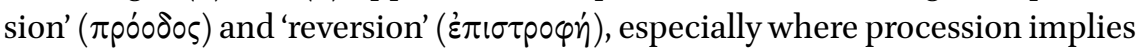
the detachment of an entity from its cause (i.e. in the process of coming to be in its actuality) and reversion implies the actuality of the entity inasmuch as it attains likeness to its original cause-while yet remaining distinct. Yet Maximus' first stage, 'generation' ( $ү \varepsilon \dot{v \varepsilon \sigma \iota \varsigma), ~ i s ~ w o r t h ~ c o n s i d e r i n g ~ w h e n ~ w e ~ c o m-~}$ pare with Proclus' stage of 'remaining' ( $\mu$ ovn'). First, whereas Maximus consid-

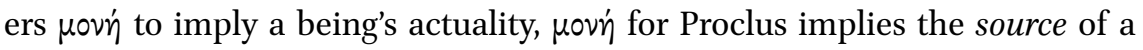

\footnotetext{
26 Cf. above, n. 22.

27 Maximus the Confessor, Ambiguum 7, 6,1-12 (PG 91: 1072A-B).

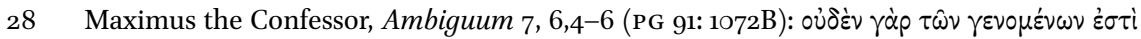

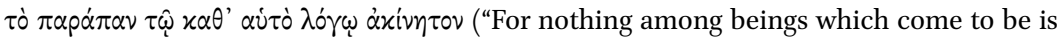
entirely unmoved by its own account").
} 
being's coming to be in procession and reversion-while ह̇ंı that being's perfection or actuality. But more importantly, Maximus does not relate the first stage of a being to its cause, as Proclus' first stage does, but rather to the very fact of its generation. This would correlate with Maximus' strong emphasis on creatures having their existence in motion in contradistinction to God's existence as outside motion, ${ }^{29}$ which implies a sharp discontinuity between God and creatures. Contingency then marks the essence of beings existing in motion in a way one does not find in Proclus' framework. We can see this later in Ambiguum 10 when Maximus establishes that the being of creatures — not just their accidents—are characterized by place and time:

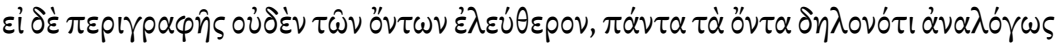

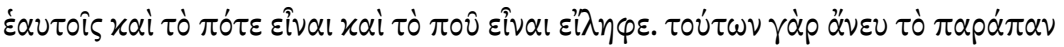

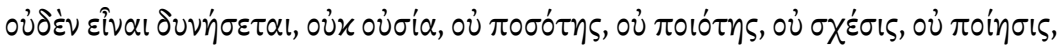

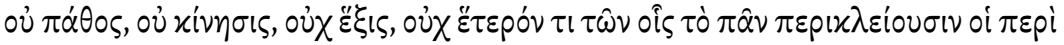
$\tau \alpha \hat{\tau} \tau \alpha \delta \varepsilon เ \nu \circ i ́$.
\end{abstract}

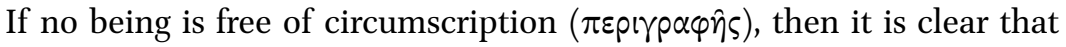
all beings have also taken being 'sometime' and being 'somewhere' in an analogous way to their own being. For without these absolutely noth-

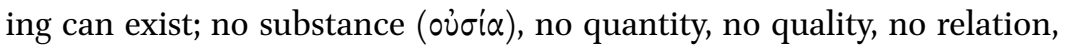
no affection, no motion, no disposition nor something else of the $<$ categories $>$ in which the experts in these matters enclose all things. (trans. Steel, modified)

MAXIMUS THE CONFeSsor, Ambiguum 10, 93,7-13 (Constas; PG 91: 1181A-B)

Given that Maximus references the ten categories which go back to Aristotle's Categories, one might expect that substance is the fundamental feature defining place and time rather than vice versa. ${ }^{30}$ Although Aristotle and other Neoplatonists would agree for physical beings, Maximus' claim goes further

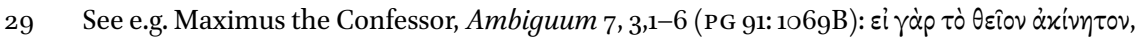

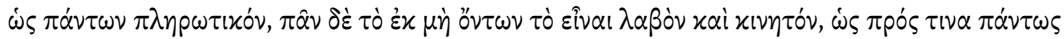

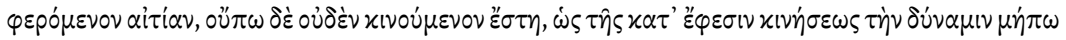
$\tau \hat{\omega} \varepsilon \dot{\varepsilon} \sigma \alpha \dot{\alpha} \tau \omega \pi \rho \circ \sigma \alpha \nu \alpha \pi \alpha \hat{v} \sigma \alpha \nu$ o $\rho \varepsilon \kappa \tau \hat{\varphi}$ ("For if the divine is unmoved—since it fills all thingswhile everything which receives being, which is from non-being, is also moved-since it is in all ways bourn along toward a given cause - then nothing that is moved has yet [come to rest], since its potentiality for motion according to desire has not yet come to rest in its final desire" - trans. Constas, modified). For a further discussion of Maximus on place and time, alongside Eriugena's interpretation of Maximus' view, see Steel 2014, esp. p. 292-304. See e.g. Aristotle, Categories, 5, 2a13-b17. 
insofar as all beings marked by a beginning are necessarily bound by time and place. ${ }^{31}$ In turn, then, all beings (öv $\left.\tau \alpha\right)$ are demarcated by place and time. ${ }^{32}$ Consequently, God is 'beyond being' in perhaps a more radical way than a Neoplatonic notion of the One's existence as 'beyond being': ${ }^{33}$ for Maximus 'being' implies delimitation by place and time, whereas 'being' for late Neoplatonists, as for Proclus, implies a composition of both unity and power. ${ }^{34}$ Where the One transcends 'being' by lacking the duality of unity and plurality — simply by its sheer unity—God, for Maximus, transcends 'being' by lacking such delimitation in time and place. ${ }^{35}$

31 See later on in Maximus the Confessor, Ambiguum 10, 92,12-16 (PG 91: 118oD-1181A): દi $\delta \dot{\varepsilon}$

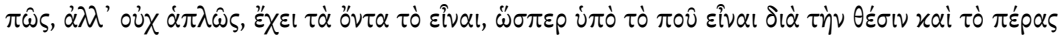

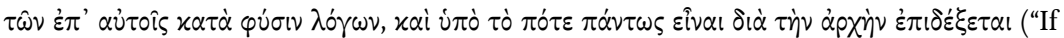
all beings possess being in some qualified way $(\pi \hat{\omega} \varsigma)$, but not simply $(\dot{\alpha} \pi \lambda \hat{\omega} \varsigma)$, then just as all beings fall under the $\langle$ category $\rangle$ 'somewhere' because of the position and the limitation due to their natural reason-principles $\left(\lambda\right.$ ó $^{\circ}$ ), they also fall absolutely under the 〈category〉 'at some time' because of their beginning" - trans. Steel, modified).

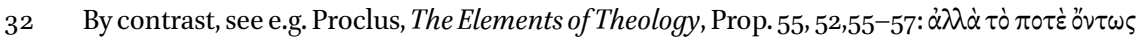

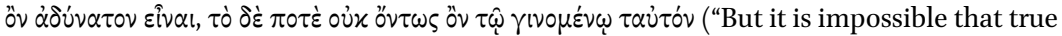

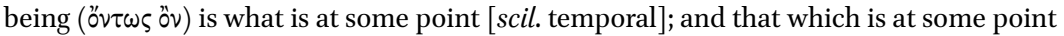
which is not true being is the same as coming-to-be"). Cf. Steel 2014, p. 299-303, esp.: "It is clear, then, that place and time are not just conditions for the existence of the physical world-in this sense even Aristotle could say that there is no movement without place and time - but that they must be understood as the ontological conditions for whatever exists apart from the creator."

33 Compare with D'Ancona 2011's claim in p. 44-45: "It has been suggested by [Charles] Kahn in a groundbreaking article that existence in the modern sense becomes a central concept in philosophy only in the period when Greek ontology is radically revised in the light of a metaphysics of creation: that is to say, under the influence of Biblical religion. As far as I can see, this development did not take place with Augustine or with the Greek Church Fathers, who remained under the sway of classical ontology. The new metaphysics seem to have taken shape in Islamic philosophy, in the form of a radical distinction between necessary and contingent existence: between the existence of God on the one hand, and that of the created world on the other." This claim, however, needs some qualification in this case with Maximus and John Philoponus (ahead), especially where Maximus' emphasis on beings as conditioned by time suggests the very innovation that D'Ancona notes in Islamic philosophy.

34 Cf. Proclus, The Elements of Theology, Prop. 89, 82,1-6.

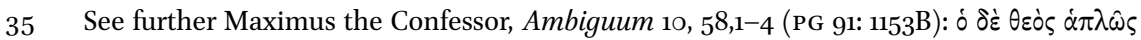

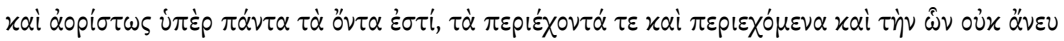

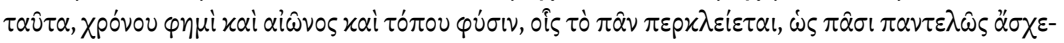
$\tau \circ \varsigma \breve{\omega} \nu$ ("God exists absolutely and without determination beyond all beings, both what circumscribes and what is circumscribed, and the nature of those [conditions] without which none of these could be, I mean, time and eternity and place, by which the universe is enclosed, since He is completely unrelated to anything" - trans. Steel). 
Thus if we look back to Maximus' causal triad, one of the main emphases we find is in the sheer contingent nature of created beings: one cannot trace a necessary, direct line from created beings back to God as cause, at least straightforwardly. ${ }^{36}$ Another way is then needed to account for creatures' origin in God as cause.

Despite the emphasis on creatures' discontinuity with God, Maximus still finds a way to make sense of Gregory's claim that we are a 'portion' of God ( $\mu \circ i$ p $\alpha \nu$ $\theta \varepsilon \circ \hat{v})$. After his discussion of the triad of created beings, Maximus introduces the notion of logoi as that by which God creates beings when he references the Book of Wisdom 9:1-2 from the Septuagint, where God is said to create all

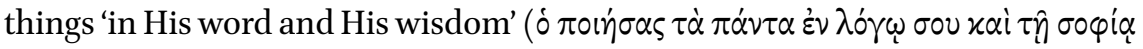

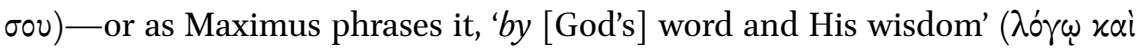

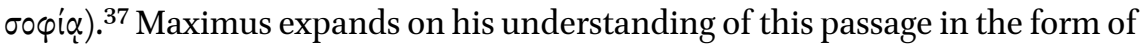
both God's singular Logos —implicitly the second person of the Trinity ${ }^{38}$ —and God's plural logoi, which we see elaborated here:

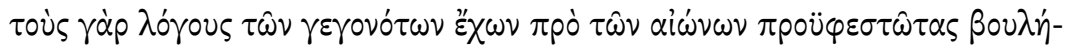

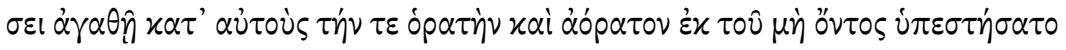

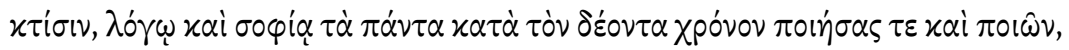

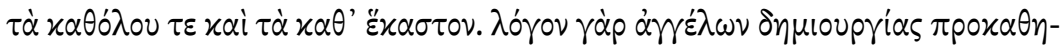

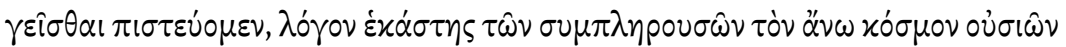

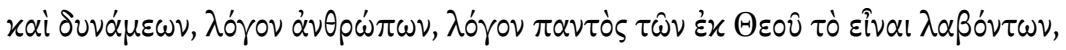
iv $\mu \mu \dot{\eta} \tau \dot{\alpha} x \alpha \theta^{\prime}$ है $x \alpha \sigma \tau 0 \nu \lambda \varepsilon \dot{\varepsilon} \gamma \omega$.

$36 \quad$ Damascius here could be a relevant late Neoplatonic mirror to Maximus' understanding of created beings' relation to God: Damascius, in contrast to Proclus, ends up denying that the first principle (i.e. the Ineffable - rather than the One, as in Proclus) has any causal relation to all things ( $\tau \dot{\alpha} \pi \dot{\alpha} v \tau \alpha)$; instead all things are produced from the One as a subordinate principle under the Ineffable. In one sense the One and all things, for Damascius, have a contingent relation to the Ineffable as the absolute, first principle. On this cf. M.-C. Galpérine's commentary in Damascius 1987 (albeit she notes the connection in a general, Christian context). On Damascius, see Van Riel 2010 and Greig 2021.

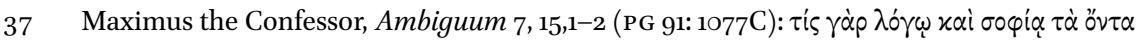

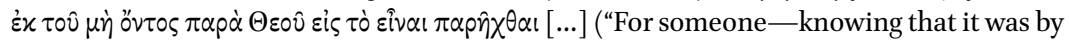
reason and wisdom that God brought all things from non-being into being [...]").

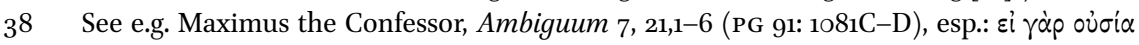

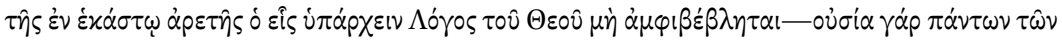

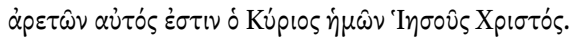




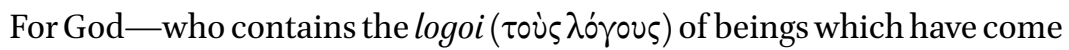

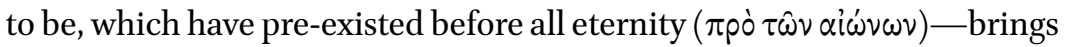
to existence by his good will both visible and invisible creation, according to themselves, from non-being: by reason $(\lambda \circ \gamma \omega)$ and wisdom did [God] make, and [continues to] make, all things according to the right time, both universal ( $\tau \dot{\alpha} x \alpha \theta \dot{\lambda} \lambda \circ v)$ and particular beings ( $\left.\tau \dot{\alpha} x \alpha \theta^{\prime} \varepsilon^{\prime} x \alpha \sigma \tau o v\right)$. For we believe that a logos (1) precedes the making of the angels; a logos (2) [precedes the making] of each of the beings and powers which fill the heavens above; a logos (3) [precedes the making] of humans; and-so that I do not speak of individuals ${ }^{39}$ —a logos (4) [precedes the making] of all things which have taken [their] being from God.

MAXImUs The CONFessor, Ambiguum 7, 16,1-9 (Constas; PG 91: 108oA)

First, we find here that there is not just one logos, but rather a plurality of logoi by which God 'brings to existence' (i $\pi \varepsilon \sigma \tau \eta \dot{\sigma} \sigma \tau 0$ ) all created beings. For Maximus the plurality of logoi corresponds to the plurality of created beings, while each particular logos implicitly has a distinct role in the generation of each kind of being, whether universal or particular. Initially this suggests that each particular logos has a paradigmatic, causal role behind each particular kind of being in creation. We see this brought out in Maximus' description of the different classes of beings which have distinct logoi attached to them: both (1)

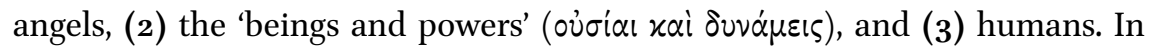
addition to these particular logoi, Maximus also affirms a distinct logos for all created things generically, and not just for the particular kinds as above. This also goes with Maximus' specification that God creates 'by [his] reason $\left(\lambda \hat{o}^{\prime} \omega\right)$ and wisdom' both universals ( $\tau \dot{\alpha} x \alpha \theta \dot{\partial} \lambda \circ \nu$ ) and particulars ( $\left.\tau \dot{\alpha} x \alpha \theta^{\prime} \varepsilon \ddot{\varepsilon} \varkappa \alpha \sigma \tau \sigma \nu\right)$. In this respect God is causally responsible in a direct way for particulars as well as universals through the logoi. At the same time, it is noticeable that Maximus refers to each particular logos possessing a distinct domain of causality, such that it is not God (or the Logos) generically that is causally responsible for each kind of being - but rather God is responsible for one kind of being in virtue of one specific logos, while for another kind of being God is responsible in virtue of another specific logos, and so on.

We also see an implicit yet important qualification in our passage when

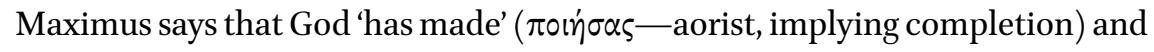
'[continues to] make' ( $\pi \circ \omega \hat{\omega} \nu$ — present, suggesting continual process) all things 
according to the logoi. The distinction in verbal aspects, although a minor point, suggests that the created products of the logoi are not brought about as the result of a necessary causal process-as, for instance, the production of heat from the sun ${ }^{40}$ - but rather they are only brought about at their 'proper time.41 This would be in contrast to a Platonic view of Forms, for example, where the products of the Forms are always brought about by necessity: e.g. the Form, 'Man', will always bring about particular men in exactly the same way, not just at certain times, and certainly not as the result of a distinct operation of intention or will. One may then see another counter to the Origenist notion of pre-existence, or the notion of necessitated creation from God: the products of the logo $i$ are contingent compared to the logoi which are eternal and necessary, insofar as they are pre-contained in God. As we will see, this line of argumentation is one that Maximus adopts from Philoponus within the latter's theory of God's possession of the logoi of created beings.

Given Maximus' position above that the logoi 'pre-exist before all eternity'

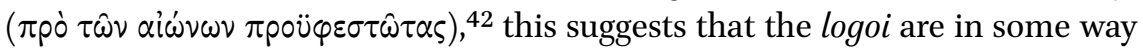
directly identified with God, inasmuch as God also pre-exists the 'eternity' that pertains to created beings. ${ }^{43}$ We see this later on with Maximus' identification

40 A common example used by those like John Philoponus to attack the notion of necessitated causation in God: see below, p. 140, incl. n. 8 o.

41 On Maximus connecting God's productivity specifically with will $(\theta \dot{\varepsilon} \lambda \eta \mu \alpha)$ and inten-

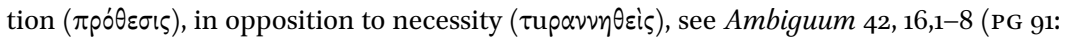
${ }_{1329}$ C-D). Cf. Gregory Nazianzen, Orationes 29.2, where Gregory critiques the notion of

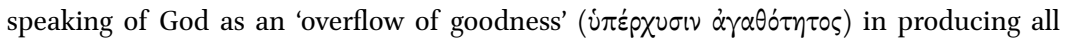

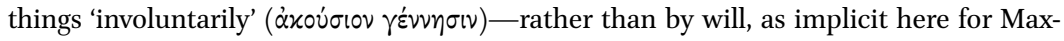
imus; for further discussion see Constas 2017, p. 5, esp. n. 15. One should note here for

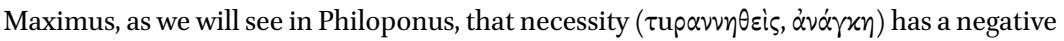
sense, implying compulsion, rather than a positive sense, as the result of one and the same operation. Compare with Plotinus on these two senses in considering the One's produc-

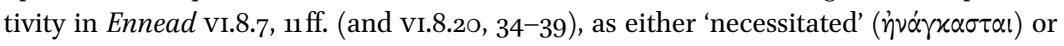
'self-determined' ( $\alpha$ i $\tau \varepsilon \xi o v \sigma i o v)$ - although note that for Plotinus, the One's singular activity of willing itself is simultaneous with willing its productivity; as we will see below, Philoponus emphasizes that these must be two distinct aspects: God's activity of his own being (i.e. his possession of the logoi), and God's willing of creation. On this, see below p. 139 , incl. n. 78 .

42 Cf. Maximus' discussion of the logoi's eternal existence in God in Ambiguum 42, 15,2037 (PG 91: 1329A-C), esp. lines 31-37 (1329C) where Maximus establishes that the logoi of

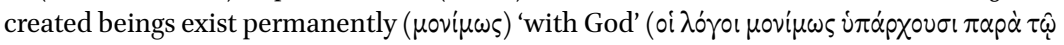
$\Theta \varepsilon \hat{\omega})$.

43 Cf. Steel 2014, p. 301, n. 16, commenting on Maximus' use of the term in Ambiguum 10, 58,3 (PG 91:1153B): "Aîे $\omega$ is not the eternity of the divinity, but the shared eternity (or eviternity) of creation." 
of the many logoi with the one Logos — and simultaneously the Logos' transcendence over all things:

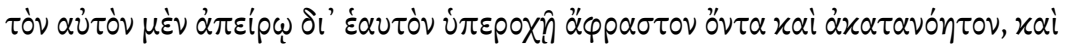

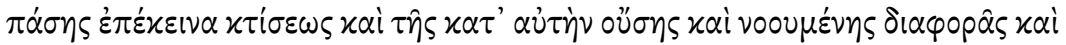

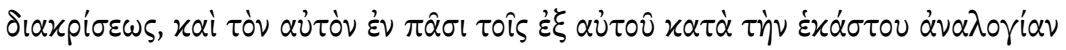

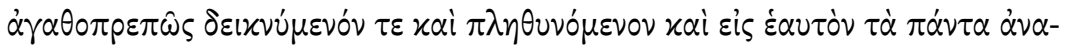

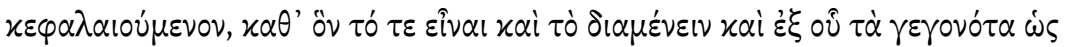

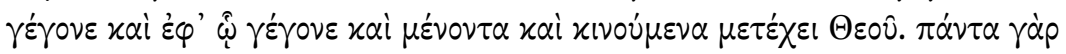

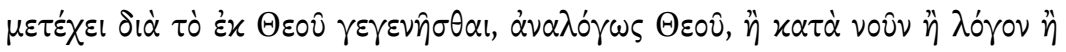

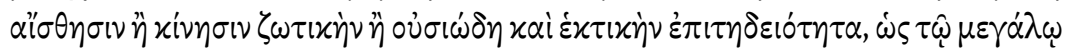

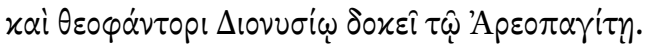

The same [Logos] is (1) through Himself ( $\left.\delta \iota^{\prime} \dot{\varepsilon} \alpha u \tau \dot{0} v\right)^{44}$ unspeakable and incomprehensible by his unlimited superiority, and He is beyond every creation and every being according to Himself, and beyond [every] differ-

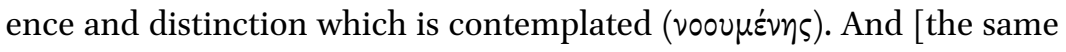
Logos] is (2) both manifested and pluralized in all things which are from him by the analogy of each in a way befitting his goodness, and all things are summed up ( $\left.\dot{\alpha} \nu \alpha \varepsilon \varepsilon \varphi \alpha \lambda \alpha 1 \circ v_{\mu} \varepsilon v 0 v\right)$ into the same [Logos] by which all things exist and persist, and [just as] from which created things have come to be and for which [they] have come to be; and all things which remain and are moved participate in God. For all things participate [the Logos] through having come to be from God, in an analogous way to God, either by intellect; by reason; by sensation; by animated motion ([น $\alpha \tau \dot{\alpha}]$

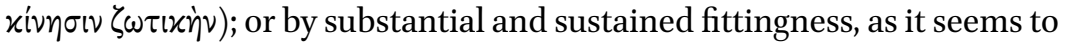
the great theologian, Dionysius the Ps.-Areopagite. ${ }^{45}$

MAXIMUS THE CONFESSOR, Ambiguum 7, 16,10-22 (Constas; PG 91: 1080A-B)

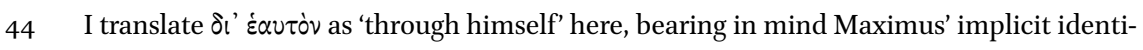
fication of the singular 'logos' with the second, divine person of the Trinity.

45 Maximus also employs this same distinction later on esp. in 20,1-5 (PG 91: 1081B-C): $\dot{\tau} \pi \varepsilon-$

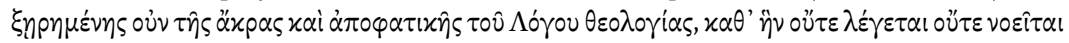

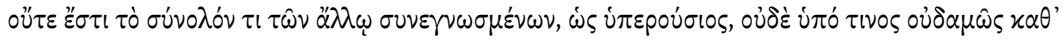

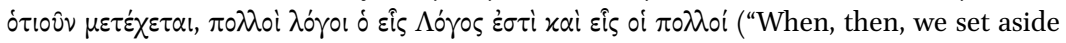
the highest form of negative theology about the Logos - according to which He is neither spoken, nor thought (

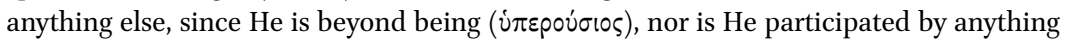
in any way whatsoever - the one Logos is the many logoi, and the many [logoi] are one [Logos]"). Note the stronger emphasis on the Logos' (implicitly God's) transcendence as

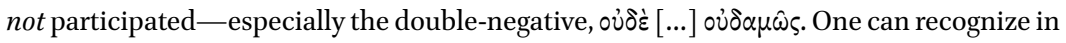


Maximus thus applies a two-fold distinction to the Logos: (1) in itself (or Himself) the Logos transcends all relation and is beyond every creature, and all being; and (2) as 'manifested and pluralized in all things' ( $\dot{\varepsilon} \nu \pi \hat{\alpha} \sigma \iota[\ldots] \delta \varepsilon \iota x v u_{-}$ $\mu \varepsilon v o ́ v \tau \varepsilon$ xai $\pi \lambda \eta \theta u v o ́ \mu \varepsilon v o v)$, the Logos is identified with the many particular logoi by which the different aspects and kinds of created beings are produced. Notably in the latter half of the passage, Maximus lists the varying activities of beings which correspond to their respective logoi: intellection (vóvs), rea-

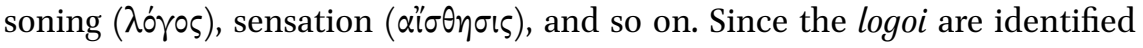
with the one Logos, each of these activities then implies a direct participation in the one Logos. Put this way, one might wonder if this only brings us back to the original problem at the beginning with the Origenist mis-interpretation, if each of these activities is directly related to God's being — an issue from which Maximus wishes to steer clear from the beginning. Likely with this in mind, Maximus establishes a distinction (1) with the Logos' transcendence 'through Himself' ( $\delta \iota^{\prime}$ ' $\left.\alpha u \tau \dot{0} v\right)$ ), both beyond created beings and even the logoi that are the Logos as manifested. On the one hand this secures the transcendence of God in Himself, as prior to created beings, while God yet remains immanently related to created beings as a cause through the logoi as particular 'manifestations' of the Logos. This would suggest that Maximus affirms some form of ontological distinction in God as 'through Himself' and as 'manifested and pluralized' in a way that captures both the absolute transcendence of God's being, in relation to creatures' being, and the means by which God creates beings in time through these 'manifestations'.

One further, important aspect to note is that the logoi not only function as efficient, paradigmatic causes, as we have seen, but they also convey divine providence. We see this when Maximus cites "Dionysius the Areopagite", as the follower of the apostle Paul, in his interpretation of the logoi:

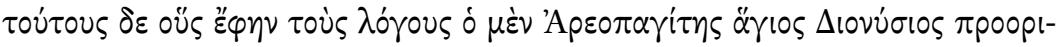

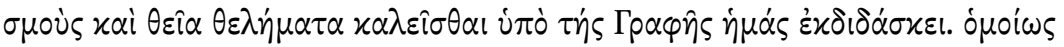

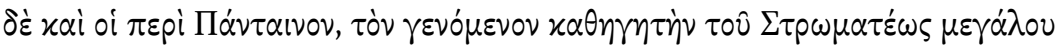

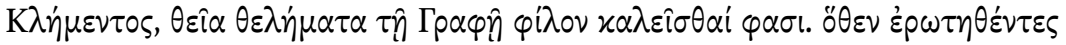

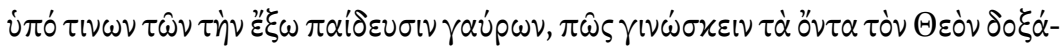

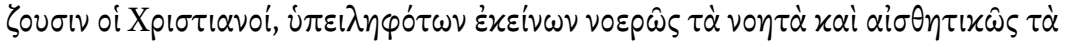

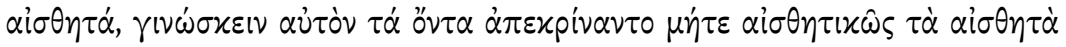

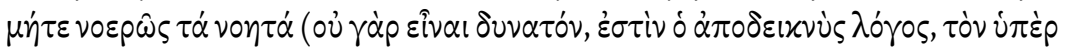

this passage Maximus' inheritance of Dionysius' characteristic superfluidity in language,

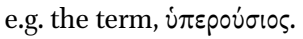




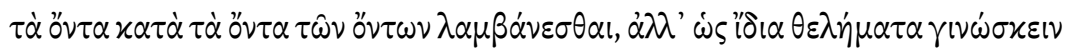

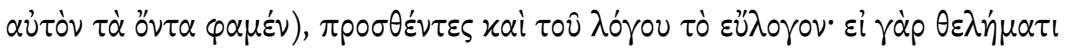

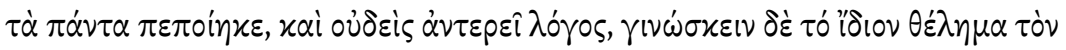

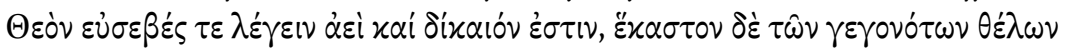

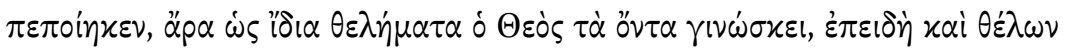
$\tau \dot{\alpha}$ oै $\tau \tau \alpha \pi \varepsilon \pi \circ i \eta \eta x \varepsilon v$.

Saint Dionysius the Areopagite teaches us that Scripture calls these logoi

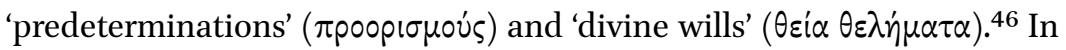
the same way, the disciples of Pantainos (who became the teacher of the great Clement [who wrote the] Stromateis) also say that they are called by Scripture 'divine wills'. For when they were approached by some of those who boast in their secular learning, and [were asked] how Christians believe that God knows beings ( $\tau \dot{\alpha}$ óv $\tau \alpha)$ — since each believed [God knows] intelligible beings in an intellective way, and sensible beings by sensation - they answered that God neither knows sensible things by sensation nor intelligible things in an intellective way (for it is not possible, as the argument demonstrated, for that which is beyond beings to apprehend beings according to the mode of beings ( $\left.\varkappa \alpha \tau \alpha^{\prime} \tau \alpha^{\prime} \delta \dot{v} \tau \alpha\right)$, but we say that [God] knows beings as his own wills ( $\dot{\omega} \varsigma^{\prime}(\delta 1 \alpha \theta \varepsilon \lambda \hat{\eta} \mu \alpha \tau \alpha)$ ), and they added the following reasonable statement of the account: for if (1) [God] has made all things by will—and no one denies the statement—and if (2) it is always pious and right to say that God knows his own will, and (3) [God], as willing, has made each of the things that have come to be, then God therefore knows beings just as his characteristic wills ('i $\delta 1 \alpha \theta \varepsilon \lambda \eta \dot{\eta} \mu \alpha \tau \alpha)$, since, as willing ( $\theta \dot{\varepsilon} \lambda \omega \nu)$, He has made beings.

maXimus the CONFessor, Ambiguum 7, 24,1-20 (Constas; PG 91: 1085A)

Hence for Maximus, God has direct knowledge of both intelligible and sensible beings, albeit not in the mode of their being as intelligible or sensible, but rather in transcending them. While it would make sense that God, as incorporeal, does not know beings 'by sensation' ( $\left.\alpha i \sigma \theta \eta \tau \varkappa \omega^{\prime} \varsigma\right)$, one may wonder why God also does not know beings 'in an intellective way' (vorpw's), especially if knowledge would imply intellection. Maximus' stated answer above is that God transcends all beings, both sensitive and intelligible—-that is, insofar as God

46 Or more literally, 'intentions', or 'contents' of will ( $\theta \varepsilon \lambda \eta \dot{\mu} \mu \tau \alpha)$. The English word, 'wills' can sometimes convey both the process or activity of willing (i.e. $\theta \dot{\varepsilon} \lambda \eta \sigma ı \zeta)$ and the result or product, i.e. intention, of willing $(\theta \dot{\varepsilon} \lambda \eta \mu \alpha)$. It should be evident in this context Maximus means the latter. 
has created intelligible beings, God's knowledge cannot be of the same kind that pertains to intelligible beings, implicitly intellection. However, there is also a second reason for which Proclus becomes relevant, as we will see: Maximus may be following an implicit premise held by Aristotelians and Platonists that knowledge through intellection pertains to universals as its object, ${ }^{47}$ while individuals are not knowable, strictly speaking, except as instantiations of universals. Thus, for Maximus, if divine providence encompasses particulars, and not just universals, the kind of knowledge possessed by God would have to be beyond intellection. Once more we find an implicit agreement with Proclus' position, where Proclus also argues for the knowledge of individuals in divine providence, and that such knowledge necessitates principles that exist prior to intellection - which, for Proclus, means pure unity beyond intellection. ${ }^{48}$

We see this argument implicitly made in Ambiguum 10, where Maximus proves that divine providence extends to particulars and not just to universals—an implicit Peripatetic position Maximus argues against, ${ }^{49}$ represented especially in Alexander of Aphrodisias' De Providentia..$^{50}$ Maximus concludes that providence $\left(\pi \rho \delta^{v o l \alpha}\right)$ -

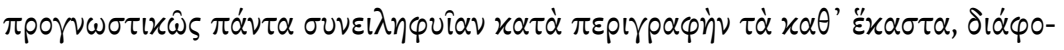

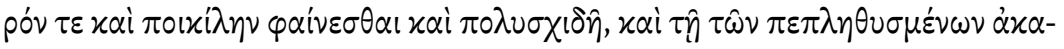

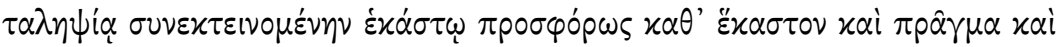

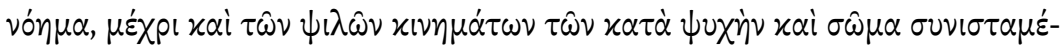
$\nu \omega \nu, \dot{\alpha} \rho \mu o ́ \zeta \varepsilon \sigma \theta \alpha$ l.

47 See e.g. Aristotle, De Anima III.6, esp. 43ob6-20, on the nature of thought corresponding to the indivisible character or element between divisible things, and implicitly not divisible things (or particulars) qua divisible; among Platonists, see e.g. Proclus, De decem dubitationibus circa providentiam 3,12-19.

48 On his argument for divine providence extending to particulars, cf. Proclus, Theologia Platonica I.15, 70,23-25; on the mode of knowledge implied in divine providence, see the first problem of Proclus' De Dec. Dub. 2,1-5,39.

49 Maximus the Confessor, Ambiguum 10, 103,17-21 (PG 91: 1192D): ' $\varepsilon \dot{~} \delta$ '

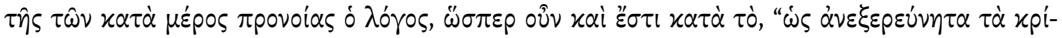

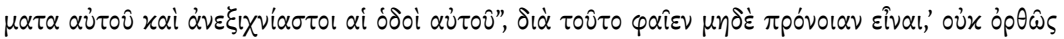

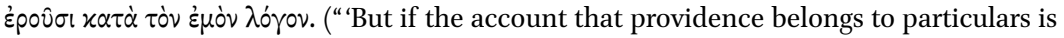
incomprehensible to us-as it then certainly is according to [the verse], "His judgments are unsearchable, and His ways inscrutable" [Rom. 11:33] — because of this they would say providence does not exist', they do not inquire correctly according to my position".) Constas references Nemesius, De natura hominis 43, 133,2-5, behind this quotation.

50 On Alexander's view of providence as a mediary, 'Aristotelian' position against the Stoics (viz. God's/the gods' providence extending to particulars) and the Epicureans (viz. the gods' providence exercising no providence or causality on any beings), see Sharples 1982. 


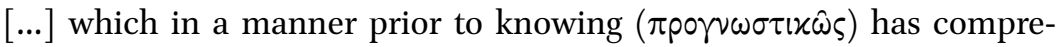
hended all particulars in their individuality—is manifested as different, diversified, and complex, and adapts itself to the incomprehension of the things which have been multiplied, extending itself in a suitable way to each particular thing and thought as far as the bare movements of beings put together according to soul and body.

MAXIMUS THE CONFESSOR, Ambiguum 10, 104,10-15 (Constas; PG 91: 1193A)

Providence is then presented as comprehending things that are 'incomprehensible' on a particular level, because of the sheer plurality of details or things that pertain to one individual or another. This would then make sense of Maximus' use of $\pi \rho \circ \gamma v \omega \sigma \tau i x \omega \bar{\omega}$, 'prior to knowing', inasmuch as knowledge grasps something unitary rather than a plurality, whereas providence is able to grasp individuals in a way that knowledge ( $\gamma \nu \omega \dot{\sigma} \varsigma)$ is not able in a straightforward way. As we will see, this suggests that Maximus' conception of the logoi as thought by God comes close to Proclus' description of providence as a mode of knowledge that transcends intellect (vovs) and reflects the nature of the principles of beings as also beyond intellect in themselves.

\section{3} Interpreting Maximus' logoi, and Proclus' Contribution

In laying out Maximus' understanding of the logoi, one basic question regards the logoi's ontological status in relation to God: are they to be understood as thoughts in the mind of God, along the lines of a Middle Platonist notion as found in Alcinous?51 Or do they have some form of independent existence in relation to God-for instance, as in Philo of Alexandria? ${ }^{52}$ Or alternatively is there some middle ground between these two options?

51 See Alcinous, Didaskalion X.3. For a similar notion in Augustine with his concept of the rationes seminales as existing in the mind of God, see e.g. De Genesi ad litteram VI.10.17; cf. Sorabji 1983, p. 302-304. Philoponus' view of the logoi in God also appears to follow a similar view, as equated with the mind of God, as we will see below.

$5^{2}$ Beyond Philo's general inspiration for Maximus with the language of the logos, one can detect a specific parallel in Philo's subtle distinction between God and the logos by which God creates beings: on the one hand, Philo strongly emphasizes God's simplicity and transcendence (see e.g. De Vita Contemplativa 2; Quaestiones in Genesim 2.68), even perhaps over the logos itself, yet Philo also identifies the logos as a production, and even manifestation, of God (e.g. De confusione linguarum 146; Quaest. in Gen. 4.1). For further analysis of Philo, see Boys-Stones 2017, p. 158-159, esp.: "One way of thinking about Philo might be to say that he is caught between Position 2 (that the forms are posterior to God) and Position 3 (that the forms are included within a second god). Or rather: he is structurally 
One reason we might aim for the first interpretation lies in Maximus' identification of the logoi with the one Logos, where the Logos' possession of the logoi would be analogous to Alcinous' God containing the Forms of all beings in the created world: the Forms as God's thoughts are then reciprocally identical with God's being and not distinct. ${ }^{53}$ On the other hand one may prefer the second interpretation - an independent, or quasi-independent, distinctionwith Maximus' distinction between God's transcendence 'through Himself' ( $\delta 1$ '

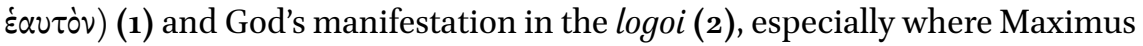
emphasizes that God cannot be participated by creatures according to their respective natures. The logoi would then be ontologically distinct in a way that implies that they are mediated causes, each functioning as distinct, separate causes. Yet the problem with this interpretation is that it fails to make sense of Maximus' identification of (1) and (2), where God is the agent and sole cause of beings in his capacity both as unparticipated (1) and as 'manifested and plural-

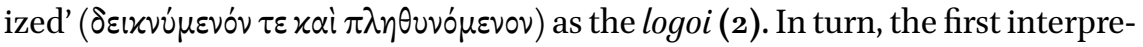
tation, straightforwardly equating the logoi with God's being, fails to account for Maximus' anti-eternalist arguments regarding God's being as entirely separate and unconditioned compared to the being of creatures - and therefore the impossibility of creatures to participate in God under this description.

Here we should consider two elements from Proclus' own framework lying behind the framework Maximus articulates for the logoi. In particular, Maximus' distinction between God in Himself and God as manifested in the logoi finds a parallel in Proclus' distinction between the first cause in itself-i.e. the One, as unparticipated - and the first cause mediated as a plurality of primary causes-i.e. the henads, as participated. ${ }^{54}$ This background, as well as Maximus' identification of God as both unparticipated and participated, finds its source in one mediator of Proclus for Maximus: the writer of the Divine Names,

attracted to Position 3, but nevertheless committed to the monotheistic view (rejected by Numenius) that the supreme god is the creator of the cosmos. The result is a system designed to produce a kind of divine agent containing the forms, from the supreme, creator god, as part of the means by which He creates the cosmos".

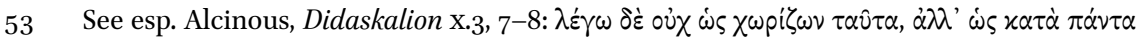

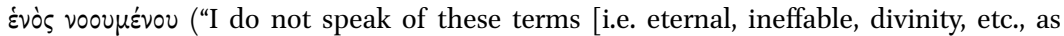
applied to God] as belonging to separate entities, but as of one entity being contemplated by all [these terms]").

54 One can already note a parallel in the language between Maximus speaking of the Logos

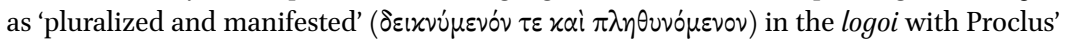
language for the henads as also 'manifested' ( $\delta \varepsilon \hat{\xi} \xi \alpha i)$ from the One in Platonic Theology

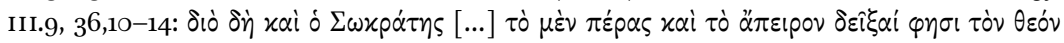

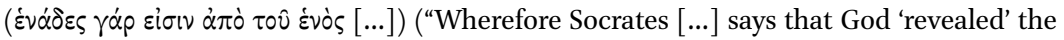
Limit and the Unlimited — for they are henads constituted from the One [...]"). 
known as Dionysius the Ps.-Areopagite. A second element of Proclus' influence

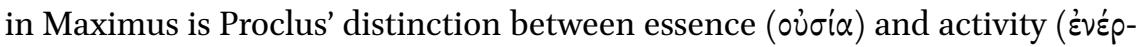
$\gamma \varepsilon(\alpha)$ in the case of the soul. The distinction becomes applied to God when Maximus distinguishes between God's possession of the logoi in eternity and God's production of those logoi in time-similar to Proclus' description of the soul's possession of its logoi in eternity (through its essence/ousia) and its productivity of the logoi in time (through its activities/energeiai). In this respect, another important intermediary between Proclus and Maximus is John Philoponus, where the latter takes over Proclus' distinction (ironically) to attack Proclus on the claim that God's eternity necessitates his eternal production of beings.

We should first consider John Philoponus' and Dionysius' respective reception and transformation of Proclus in their own frameworks, and then we may see how Maximus appropriates both figures in his own articulation of the logoi. In this light we can then see how Maximus appropriates Proclus' thought, and uniquely transforms it in light of his use of Dionysius and Philoponus.

\section{Proclus Mediated in John Philoponus: A Brief History on logoi as Causal Principles}

Although it is possible that he draws on other Christian or pre-Christian sources, like Philo, Philoponus' understanding of the logoi in God derives in large part from his Platonist background in the Alexandrian school of Ammonius, as well as his direct knowledge of Proclus. ${ }^{55}$ Thus to understand Philoponus' framework, we should first look at the Neoplatonist sources on logoi behind Philoponus.

The notion of the logoi as creative principles permeating the world goes back to the Stoics' notion of 'generative' or 'seminal' reason-principles ( $\lambda$ ó $\sigma \pi \varepsilon p \mu \alpha \tau i x \circ i$ ) - directly analogous to the notion of physical seeds, for example in plants, that are the bearers of their fully-formed products in potentiality. For the Stoics, the logoi are immanent material principles that mould particular beings in conformity with the divine, active principle, the logos or Godwhich, in turn, is immanent in matter as a substrate. ${ }^{56}$ Furthermore the logoi are identical with the one active principle, i.e. logos, as pluralized and speci-

55 For an overview of Philoponus, including on his knowledge of Proclus and Platonists in the School of Alexandria, see Verrycken 2010.

56 See e.g. Aetius 1.7.33 ( $S V F$ 2.1027); see also Diogenes Laertius, Vitae philosophorum VII.135136. 
fied in each individual being — such as plants, animals, humans, and so on. The logos then coordinates and guides the world's development and coming to be as specified in each particular thing.

One can see the legacy of Plato's Timaeus, from which the Stoics borrow much in their own conceptualization of the logos. In the Timaeus, Plato describes the world's rational structure as coming to be through the 'Crafts-

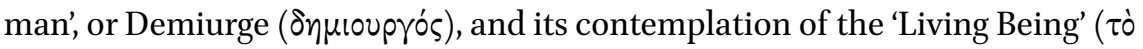
$\zeta \hat{\omega} \circ v)$, implicitly a Form or principle which contains all living beings found in the world within itself in its unity. ${ }^{57}$ For Plato, the Demiurge's productive activity according to the Living Being is brought about through its imposition of an intelligent soul in the world (i.e. the 'World-Soul'), according to which the world's rational structure is immanently brought about. ${ }^{58}$ While Plato recognizes a multi-tiered structure between the Demiurge, the Living Being, and the World-Soul as distinct immaterial principles in the physical world's rational structure, the Stoics collapse this structure by implicitly identifying Plato's 'Living Being'-alongside both Plato's Craftsman and the World-Soul—with the logos as a material principle. ${ }^{59}$

Plotinus, as the first Neoplatonist, appropriates the Stoic notion of logoi as immanent, productive principles in the world, yet in reverting back to a Platonic framework for the cosmos, Plotinus ends up critiquing the idea that the logo $i$ are sufficient unto themselves to explain the generation of things in matter. Instead, he maintains that transcendent principles which pre-exist the logoi-namely the Forms - are necessary for the logoi's ability to act in matter, like the seeds of plants. ${ }^{60}$ Implicit in this imagery is that seeds unto themselves cannot generate their product without a prior being, or paradigm, which is in actuality what the effect of the seed is potentially — a notion that goes back to Aristotle's often-cited principle that 'man causes man'. In Plotinus' ontology, the logoi then have their existence primarily in the principle, Soul, ${ }^{61}$ and

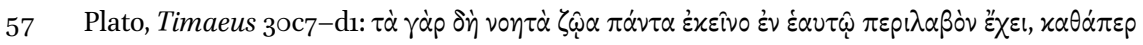

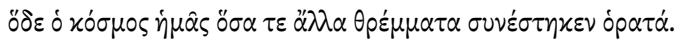

$5^{8}$ Plato, Timaeus 3ob1-c1.

59 As noted in Long, Sedley 1987, p. 278, one can see both a biological and teleological influence coming out of the Platonic and Aristotelian background with their interpretation.

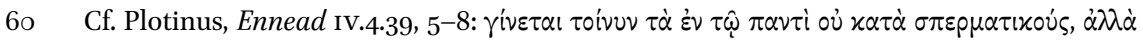

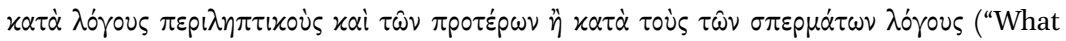
comes to be in the All, then, does not come to be according to seminal formative prin-

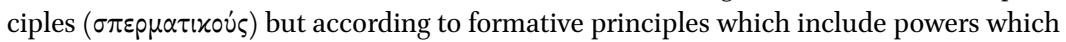
are prior to the principles in the seeds" - trans. Armstrong).

61 Plotinus particularly characterizes the being of Soul as constituted by the logoi: see Enn. VI.2.5,10-14. This would follow Plotinus' claim that Soul mirrors Intellect's being and its 
derivatively in matter through Soul's formation of the world and individual beings within the world. ${ }^{62}$ In turn, the logoi in Soul are consequent on the two higher principles of Intellect - which contains the Forms, and functions as the paradigm of Soul and its logoi-and the One - as paradigmatic of Intellect's self-thinking and unity. Thus, one important conclusion, when we compare Plotinus and the Stoics, is that Plotinus emphasizes a sharp ontological distinction between the logoi and the primary principle responsible for the activity of the logoi, in contrast to the Stoics who identify the two.

Plotinus' position effectively becomes the standard for subsequent Neoplatonists, including especially Proclus, although Proclus makes some notable changes in the structure, which become directly relevant for Philoponus. In particular, while he also affirms the primary location of the logoi on the level of Soul, ${ }^{63}$ Proclus delineates an additional ontological level below Soul, i.e. Nature, which exists immanently in matter and directly forms and holds together the properties of sensibles in accordance with their paradigms in Soul. ${ }^{64}$ Under this scheme, Proclus distinguishes between logoi in Soul and in

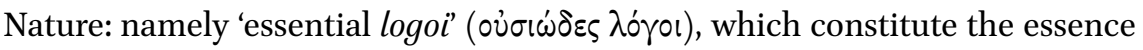

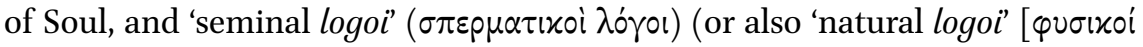

Forms, where the Soul's logoi are effectively Intellect's Forms as unfolded; on this see e.g. Enn. I.1, 8,6-8.

62 On logoi in Soul, see e.g. Enn. IV.3.10,37-42; V.7, 3,20-23; and II.3.16, 19-20. On logoi in nature and matter, see III.8, 2,27-34; IV.3, 11,8-12; V.7, 1,23-25; V.8, 1,36; and 3,1-3. Cf. Helmig 2012, p. 191-192. It should also be noted that, although not as clear as Proclus, Plotinus marks out an ontological distinction between 'nature' ( $\varphi \dot{v} \sigma \varsigma)$ and 'matter', however the distinction is blurred by certain places where Plotinus identifies nature with Soul or the operation of soul.

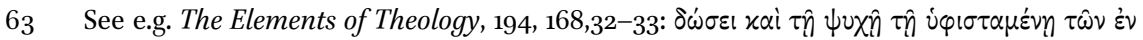

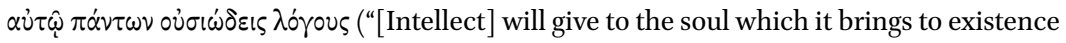
the essential reason-principles ( $\lambda$ ó yous) of all things in it"). See also e.g. The Elements of Theology, Prop 195, 170,10-13. Cf. Martijn 2010, 44ff. and 73ff.

64 On Nature as immanent in matter, see e.g. Proclus' In Timaeum, I, 10,24-11,5; cf. Martijn 2010's discussion in p. 28-30. Although there are indications of a distinct level for Nature apart from Soul, Plotinus comes to identify Nature with the lowest, non-descended part of the World Soul: see Enneads, IV.4.13 (esp. lines 3-4) and III.8.4, 14-16. While this might suggest that Plotinus denies the existence of a distinct ontological level for nature, or immanent form, in matter (as claimed by Chiaradonna 2014), there are certain texts where Plotinus seems to argue just this: on this see Karamanolis 20o9. At any rate, Proclus seems to have Plotinus in mind with his critique of those who identify Nature with Soul in In Tim. I, 10-12; for a further analysis of Proclus' critique of Plotinus and this position, see Martijn 2010, p. 29-35 and Helmig 2006; I also discuss Proclus' dispute with Plotinus in more detail in a forthcoming paper. 
$\lambda$ ó$\left.\left._{0} \mathrm{l}\right]\right),{ }^{65}$ which constitute Nature as it is divided in particular bodies. Hence Proclus replicates the paradigm-image relation between Intellect's Forms and Soul's logoi with his own schema of Soul's essential logoi and Nature's seminal logoi. Given this, even though the essential logoi exist together in the soul rather than physically separated, as for the seminal logoi in bodies, Proclus affirms the divided nature of the soul's essential logoi in relation to Intellect, insofar as the soul acts on its logoi discursively and one-by-one rather than Intellect's activity which thinks the Forms at once. ${ }^{66}$ Once more we find that the role of the logoi is both epistemological and causal: they are the means by which the soul knows all things, as derived from Intellect, and in turn they are the means by which the physical world is ordered - both through Soul's transcendent activity, with its essential logoi, and through Nature's immanent activity in matter, with the seminal logoi found in particular bodies. ${ }^{67}$ Both types of logoi can then be understood as mediated causes of their higher principles which function as unifying their products. One can see this in Proclus' characterization

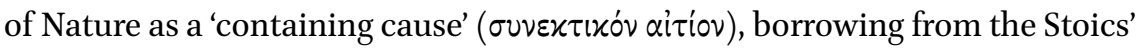
own characterization of the $\log { }^{6}{ }^{68}$ while Nature connects enmattered entities with their higher, immaterial principles. As Proclus puts it, Nature (especially in the capacity of the natural logoi) has the function of "everywhere weaving

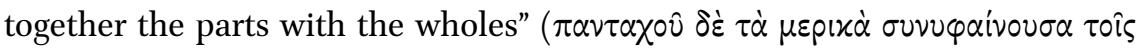

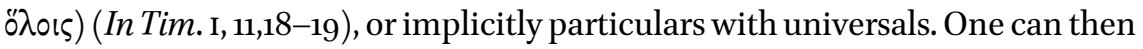
understand the logoi, especially in this latter case, as instrumental or contribu-

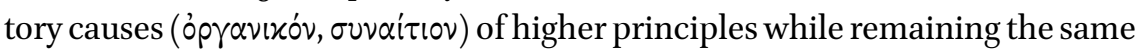
in kind as their corresponding causes. ${ }^{69}$

65 For further discussion, cf. Helmig 2012, p. 265 (on the seminal logoi) and 288 (on the natural logoi).

66 For an overview of Proclus' understanding of the soul, see Steel 1997 and Steel 1978, p. 2333, 69-73.

67 Exactly how Proclus characterizes seminal logoi in bodies compared to natural logoi possessed by Nature in general is not so clear, inasmuch as he sometimes appears to equate the two, and in other places subordinates the former under the latter: cf. Martijn 2010, p. 64 .

68 Cf. Steel 2002.

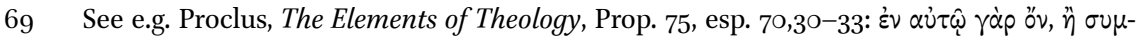

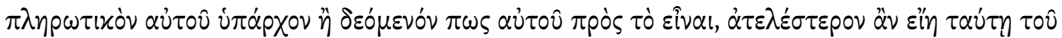

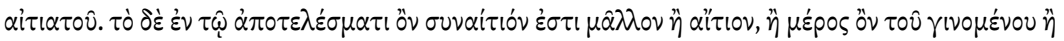

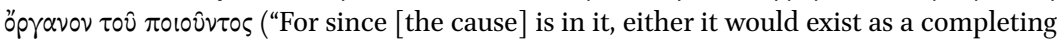
part of it, or it would in some way need it for its being, and by this it would be inferior to

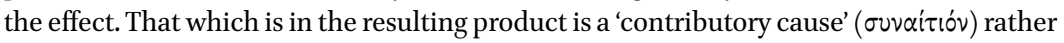

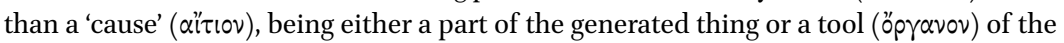
producer"). 
On turning to John Philoponus in his later, anti-eternalist writings, especially in his critique of Proclus from the De aeternitate mundi, ${ }^{70}$ we find that not only does he drop the distinction between Forms in Intellect and subordinate logoi in Soul, but he uses the language of logoi, rather than Forms ( $\left.\varepsilon^{\prime \prime} \delta \eta \eta\right)$ or paradigms, in his description of God's possession of the principles of created beings. We see this in Philoponus' critique of the idea that, if the paradigms ( $\pi \alpha \rho \alpha \delta \varepsilon i \gamma \mu \alpha \tau \alpha)$ of beings are eternal, their effects must also be eternal-and thus the world must be co-eternal with its principles of creation. Philoponus' reply to this is to emphasize the contingency of the effects of the $\pi \alpha \rho \alpha \delta \varepsilon i \gamma \mu \alpha \tau \alpha$ in contrast to the eternity of the $\pi \alpha \rho \alpha \delta \varepsilon i \gamma \mu \alpha \tau \alpha$ themselves: 'paradigm' can only be understood as a relative term, not absolute. ${ }^{71}$ Philoponus concedes that there must be principles which pre-exist their effects, but the being of these principles as paradigms does not obtain until their corresponding copies come to be. As a result, God,

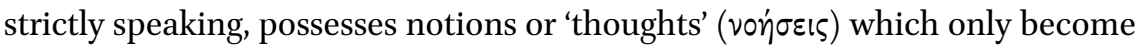
'paradigms', and therein 'Forms', when He produces beings:

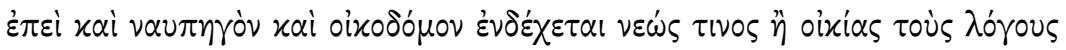

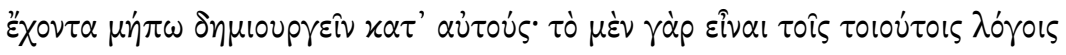

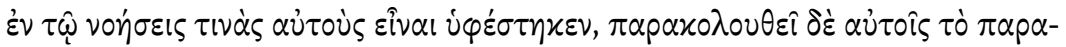

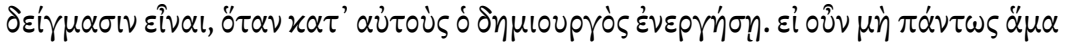

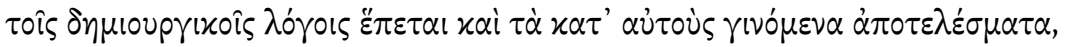

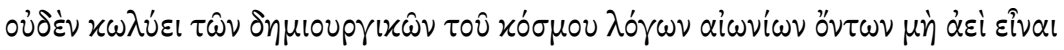

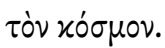

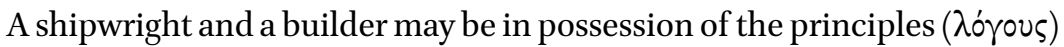
for [building] a ship or a house ${ }^{72}$ but not yet be creating [anything] based on them. The being of such principles consists in their being thoughts

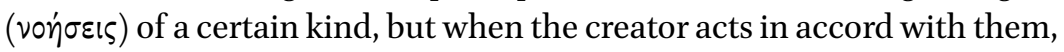
they become paradigms ( $\pi \alpha \rho \alpha \delta \varepsilon i \gamma \mu \alpha \sigma v)$ as a consequence [of that]. If, then, the generated beings based on them do not in every case imme-

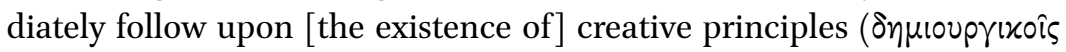

70 Here I take no explicit position about whether Philoponus changed his view of the number/kind of principles between his 'early' writings (mostly the Aristotelian commentaries) and his 'later' writings (mostly his anti-eternalist treatises against Proclus and Aristotle). On the developmentalist theory between Philoponus' 'early' and 'later' periods, see Verrycken 2010, p. 737-738 and Verrycken 199o. For a review and critique of the developmentalist position, see Sorabji 2016.

71 Philoponus, De aeternitate mundi 35,25-36,15.

72 The house-/ship-building metaphors have a heritage that goes back to the Stoics and previous Platonists: see Sorabji 1983 in comparison with Augustine in 303-305. 
$\lambda$ óyols), nothing prevents the world from not always existing even if the creative principles for the world are eternal.

JOHN PHILOPONUs, De aeternitate mundi 36,27-37,8 (trans. Share, modified)

One important point here is Philoponus' claim that the being ( $\tau$ ò gival) of the

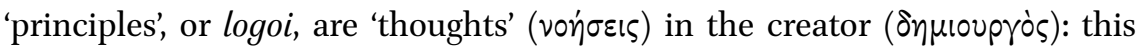
recalls Alcinous' position that Forms are essentially thoughts in the mind of God-also similar to Philoponus' master, Ammonius, in his own description of the divine Intellect. ${ }^{73}$ Yet one difference here is that the relation between logoi and their effects are contingent, in a way not present in Alcinous: the logoi exist necessarily in the mind of God, but only contingently as paradigmatic Forms relative to their products. This is also correlated with Philoponus' emphasis elsewhere on God as the direct creator of all things without any intermediate principles ${ }^{74}$-implicitly obliterating the Neoplatonic distinction of mediated causality for the physical world between the One, Intellect, and Soul. Philoponus' logoi thus capture the varying levels of logoi that were found causally in Intellect, via the Forms, and primarily in Soul, as directly involved in the world's physical formation. For Philoponus, God is directly responsible both for containing the Forms, or logoi, as thoughts, and just like Plotinus' and Proclus' Soul, God is also directly responsible for the production of physical beings.

Given this last point, one may worry that God is implicated in his effects: if God is directly related to the physical world as its immediate cause, where beings come to be and change, one might think that God must also change and be altered in mirroring the nature of his effects. This is one reason why we find the notion of mediated causality in the general Neoplatonic framework of the One, Intellect, and Soul, and especially in Proclus' distinction between unparticipated and participated causes. ${ }^{75}$ Philoponus' response to this difficulty is to say that change and alteration obtain only for things that are contingent and exist in potentiality: since God exists in complete actuality by his nature, change and alteration only happen for created beings which exist by potentiality. ${ }^{76}$ Consequently, the logoi also exist in actuality, although with a certain

73 On Ammonius and his interpretation of the divine intellect, see Blank 2010.

74 See e.g. De aeternitate mundi, 78,28-29, in the context of Philoponus speaking about God's foreknowledge of the various stars' differing locations at differing times: o j $\gamma \dot{\alpha} \rho \dot{\alpha} \gamma v 0 \dot{\eta} \sigma \varepsilon$ l

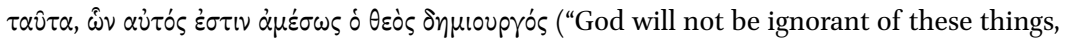
of which He is himself, without any intermediary, the creator" — trans. Share).

75 Cf. Proclus, The Elements of Theology, Prop. 23.

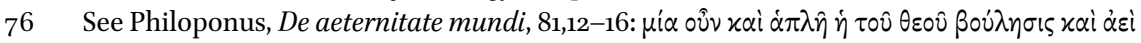

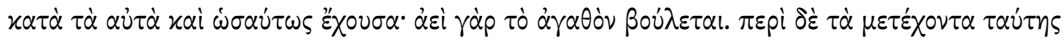

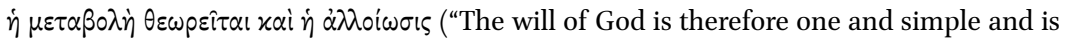


distinction: while God eternally possesses the logoi of beings, the logoi only bring about their created effects only at a certain point by God's will. Thus in relation to the logoi, God possesses a capacity for creating beings but does not always exercise it, nor is He necessitated to-analogous to Aristotle's distinction between first and second actuality, ${ }^{77}$ as for example, between a sailor who possesses knowledge of sailing (first actuality) and a sailor who is currently sailing (second actuality). ${ }^{78}$ This does not imply true change as, for instance, the sailor's transition from not-sailing to sailing in act, although Philoponus concedes that a kind of 'change' obtains in cases like this: e.g. the sailor's limbs have to move to carry out the activity of sailing. ${ }^{79}$ By contrast in the case of God, the transition from first to second actuality, or from capacity to exercising that activity, does not imply change in any sense:

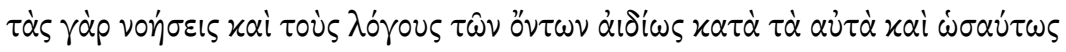

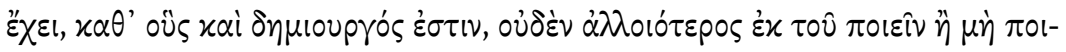

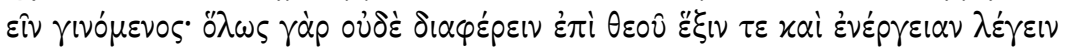

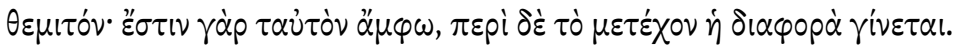

always the same and unchanging, for He always wills the good. It is in the sphere of things that partake of it [sc. God's will] that change and alteration are observed"-trans. Share). An additional premise here is that God's will does not imply alteration and changee.g. from not willing a being's existence to willing that being's existence. Whereas human

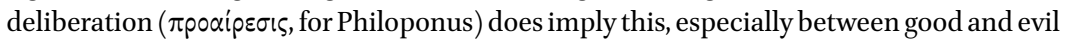

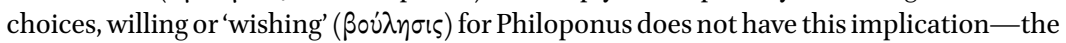
object, or objects, of goodness are always the same (see De Aet. Mun. 567,5-7; cf. Verrycken 2010, p. 747). As seen in our passage above, God for Philoponus only 'wills' ( $\beta \circ v$ $\lambda \eta \tau \alpha \iota)$ good actions.

77 Cf. e.g. Aristotle, De Anima II.5, esp. 417a22-b2.

78 See Philoponus, De aeternitate mundi, $75,26-76,9$, where he makes the distinction when he responds to the challenge that God's creation in time results in God changing; see

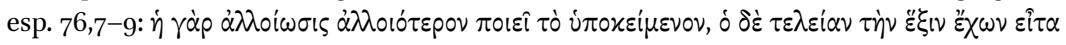

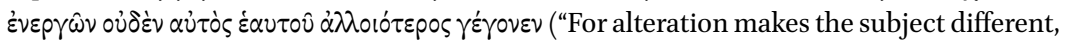
but someone who possesses a perfected capacity $(\tilde{\xi} \xi i v)$ and then acts [in accordance with it] has not become different in any respect from his [former] self"- trans. Share, modified).

79 See Philoponus, De aeternitate mundi, 76,9-21, which explains why 'change' might still occur for 'us' when moving from first to second actuality, where humans "[...] cannot achieve the appropriate outcomes by pure thought alone and as a result move into a different state of some kind, not in the realm of thought but in the realm of the instrument

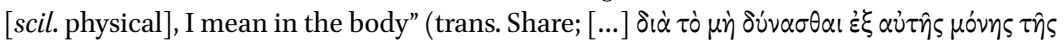

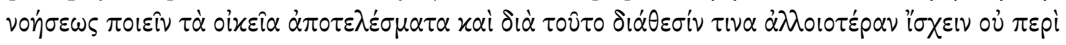

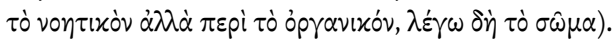




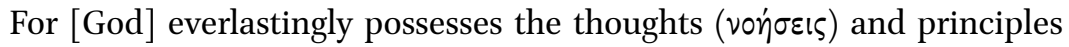
( $\lambda$ óyous) of beings, according to which He is indeed a creator, in exactly the same way, and does not become different in any respect whether He produces or does not produce. For generally, it is not right to say that capacity and activity are different [things] in the case of God: the two are one and the same thing and difference arises in the sphere of that which participates [in God].

PHILOPONUS, De aeternitate mundi $76,26-77,3$ (trans. Share, modified)

Yet even without a 'real' distinction in God, the simultaneity of God's capacity (via his possession of the logoi) and activity (with the production of beings by the logoi) does not imply an 'automatic' or 'necessary' production of beings like the production of heat from fire or the effect of illumination from the sun. ${ }^{80}$ These latter two examples in Philoponus are an implicit reference to Plotinus' distinction between primary and secondary activity: for Plotinus all beings are characterized by a primary, 'internal' activity that constitutes their essence-as in Plotinus' own example of the being of fire-and that activity correspondingly generates a secondary, 'external' activity — as with 'heat' as the correlating activity to fire. ${ }^{81}$ When taken to the level of higher principles, Plotinus uses this to explain how the One, as the first cause, produces its subordinate effect of Intellect, and how Intellect in turn produces Soul, and Soul produces the physical world. What Philoponus seems to imply in his counter-examples is that God's causality of created being cannot be the result of one operation, with his own being or perhaps even in willing his own being, ${ }^{82}$ but must instead result from an additional, distinct operation of will in God. Thus, Philoponus

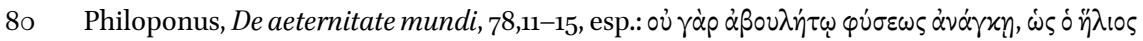

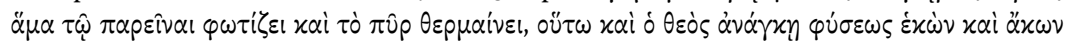

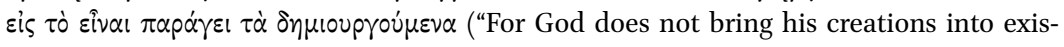
tence involuntarily $(\dot{\alpha} \beta 0 \nu \lambda \dot{\eta} \tau \omega)$ by a necessity of nature in the way that the sun illuminates and fire heats as soon as they are present by an involuntary necessity of nature" - trans. Share, modified). Philoponus' example of the sun's illumination almost certainly references Plato's analogy of the sun to the Good in Republic VI-likely making an implicit critique against the Neoplatonic interpretation of Republic's Good producing its effect like the sun as the cause of illumination: on which see the next note. Also worth comparing is the controversy in late antiquity on heat's status in relation to fire, as either part of the definition of fire or a necessary accident: on the history of this dispute, see Benevich 2017 (esp. p. 240-246).

81 Among multiple instances, see Plotinus, Enneads, II.6.3, 16 ff.; v.1.3, 9-10; 6, 34; V.3.7, 2324. For a general discussion on Plotinus' theory of internal/external activity in the case of Intellect, see Emilsson 2007, esp. p. 22-68.

82 As Plotinus holds with the One in Enneads, vi.8.7; 13; and 20; cf. above, n. 41. 
still affirms some distinction in God, inasmuch as God's being is distinct from God's acts of will ( $\beta$ ○o $\lambda \eta \sigma ı \varsigma)$ which bring about created beings.

So far we have seen how Philoponus takes over the notion of logoi from his Neoplatonic predecessors and transforms it when discussing God as the first, sole cause. Given the distinction in God between the possession of the logo $i$ and production in virtue of the logoi, we can trace one specific influence here from Proclus: the distinction in the participated soul between its essence (ov $\sigma^{\prime} \alpha$ ),

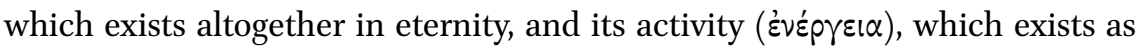
dispersed and distinguished in time. As Proclus elaborates in The Elements of Theology, Prop. 191, Soul cannot have both its essence and activity in eternity

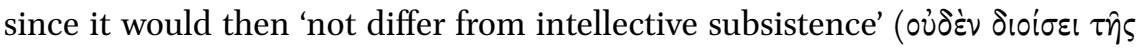

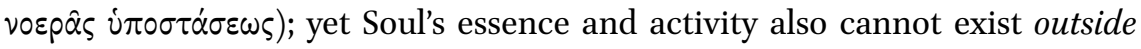
eternity, since it is self-animated ( $\alpha \dot{v} \tau o ́ \zeta \omega \varsigma)$ and self-constituted ( $\alpha \dot{v} \theta v \pi \dot{\sigma} \sigma \tau \alpha-$ $\tau \circ \varsigma){ }^{83}$ The distinction for Proclus results from the soul's intermediate state as belonging both to partless principles and that which is 'divided around bodies'

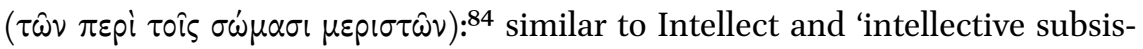

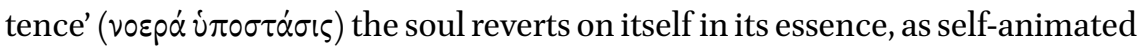
and therefore self-constituted, yet since it is characterized by life, and not just pure knowledge, and since it acts on bodily entities which exist as divided, it is also characterized as divided - via its activity. ${ }^{85}$ Considering the soul's logoi in this light, this means that while the soul possesses the essential logoi (ov $\sigma-$ $\omega \dot{\omega} \delta \varsigma \lambda \hat{o}^{\prime}(\mathrm{l})$ that constitute its being, the soul is unable to think the logoi all at once but can only do so one-by-one, i.e. discursively. In Proclus' characterization, Soul must 'project', or literally place before itself ( $\pi \rho \circ \beta \alpha \lambda \lambda \varepsilon i v)$, each logos which it contains in itself in its activity of thinking, or also correspondingly in its productive activity in physical beings. ${ }^{86}$ This would be in contrast to Intellect, whose activity of thinking is immediately at one with its being: hence its activity is simultaneous with its essence. Consequently, the inability of Soul's activity to be simultaneous with its essence-either to think, or also produce, all at once in direct conjunction with its being (ovं $\sigma^{\prime} \alpha$ ) — reflects the lower ontological status it has in relation to Intellect.

The reception of Proclus' distinction between essence and activity in the case of the logoi is striking when we look at Philoponus' own conception of

83 Proclus, The Elements of Theology, Prop. 191, 166,28-168,5.

84 Proclus, The Elements of Theology, Prop. 190, 166,2. The reference to Soul's intermediate state and as 'divided around bodies' comes from Plato's Timaeus (35a).

85 See esp. Proclus, The Elements of Theology, Prop. 189-19o.

86 See Proclus, In Parmenidem, 896,2-17 (Steel); cf. Steel 1997's discussion of this dynamic in p. $295^{-296 .}$ 
the logoi in God, where God possesses the logoi of created beings throughout eternity, yet does not bring the created product of each logos into act until its respective part in time. Where the distinction between essence and activity implies ontological inferiority for Proclus with Soul, in Philoponus the distinction is a sign of perfection in God by indicating God's transcendence over the contingency of his effects. We even find one area of correspondence when Philoponus illustrates the transition from capacity to activity in God with

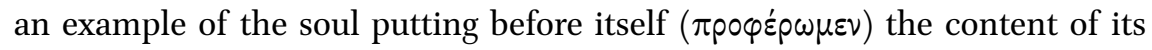
contemplation into the outside world through 'spoken knowledge' ( $\lambda \circ \gamma(x \omega \hat{\omega} \mathrm{v}$ $\dot{\varepsilon} \pi(\tau \tau \eta \mu \hat{\omega} v) .{ }^{87}$ Analogously, God then possesses the logoi of created beings by

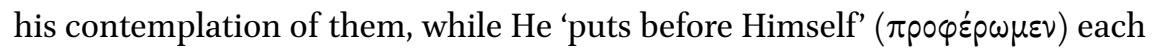
logos at its intended point in time-albeit without the type of discursivity that implies change in the case of the human soul.

However, a number of differences exist between Proclus' conception and Philoponus': it is fairly clear, for example, that Philoponus' God thinks the logoi all at once as a divine intellect, unlike Proclus' Soul which is unable to think all the logoi at once. So another qualification to Philoponus' adaptation of Proclus is that the activity in question is not of thinking each logos, but rather in enacting, or producing, each logos. Another difference is that, while the soul's activity happens in time for Proclus, for Philoponus God's activity happens in eternity inasmuch as God eternally wills the logoi that correspond to particular created beings in time. One might wonder how Philoponus can hold such a distinction in the first place: how can God both possess and will the logoi in a way that does not imply the reduction or identification of one with the other? One can see how Proclus avoids this problem by placing the soul's total possession of the logoi-its essence (ovं $\left.\sigma^{\prime} \alpha\right)$-in eternity and its distinct activ-

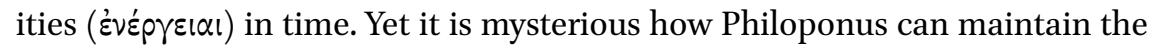
same distinction with God's logoi and activities both happening in eternity. ${ }^{88}$ If the distinction is not between time and eternity, it would seem that Philoponus needs another way to distinguish between God's (1) possession of the logoi and (2) actual production: in other words, Philoponus needs to explain how God can eternally will the world's creation (corresponding to possession [1]) and additionally will the world's real existence in time (corresponding to

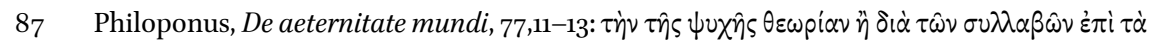

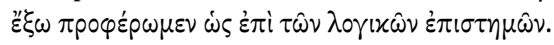

88 Verrycken 2010, p. 748, suggests that Philoponus' conception of eternity (in his 'later'/ Christian period) as supertemporal successive duration is what allows for maintaining the distinction between God's possession and willing of the logoi in eternity-with the aporetic caveat indicated in Simplicius (In Physicam, 1159,28-1161,29). 
activity [2]), where the danger is that, simply by characterizing both as happening in eternity, it risks suggesting that creation is co-eternal to God's willing activity - the exact outcome Philoponus attacks. Although Philoponus insists that the created world's nature is finite, Koenraad Verrycken notes well: "But this does not solve the problem that a separate divine volition, distinct from God's eternal will to create the world, is needed in order to bring about the real existence of the world, which would be incompatible with the immutability of God's willing activity." 89

While it is not clear how Philoponus ends up resolving this difficulty, this may help form the background for Maximus' emphasis on the distinction in God between the unparticipated and participated, a factor we have not seen so far in Philoponus. As we will next see, this becomes a motivation for Maximus to adopt Proclus' own distinction between the unparticipated and participated for the first principle-albeit as mediated through Dionysius the Ps.Areopagite.

\section{5}

\section{Assessing Maximus' Appropriation of Proclus in Philoponus}

In looking at Proclus' reception in Philoponus, we may summarize two significant factors that become relevant for Maximus: (1) in Proclus, the distinction

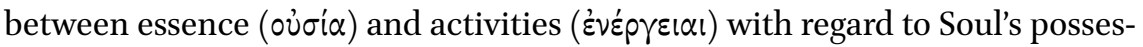

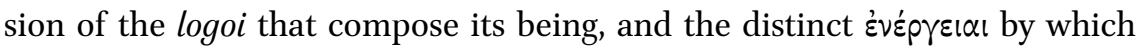
Soul brings about particular logoi within time; and (2) in Philoponus, the same distinction employed now for God, with the latter's possession of the logoi of created beings, and eternal willing of those logo $i$ in actually produced beings in

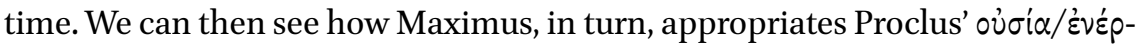
$\gamma \varepsilon ı$ la distinction through his reception of Philoponus on the logoi in God. We have already seen Maximus employ Philoponus' framework in his claim from Ambiguum 7 that God contains the logoi of all beings 'before all eternity' ( $\pi$ po $\tau \omega \hat{\omega} \nu \alpha i \omega v \omega \nu)$, and that God eternally wills the production of the logoi at their intended points in time. ${ }^{90}$ We can also see Philoponus' influence further on with the emphasis on God's status as creator by actuality:

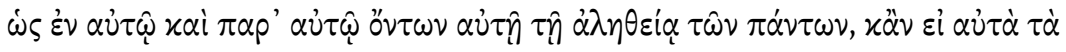

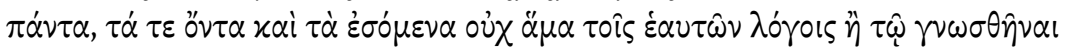

89 Verrycken 2010, p. 747.

$90 \quad$ Cf. earlier p. 128. 


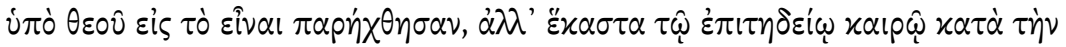

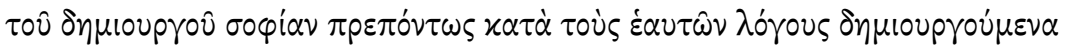

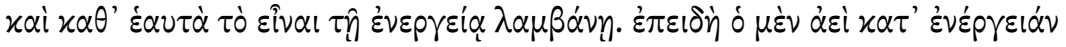

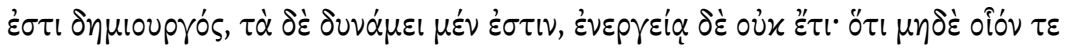

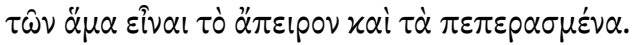

Just as by truth itself, that which is of all beings is in him and by him, even while all things - both beings which are and beings which will beare not produced together with their logoi, nor [are they produced] with their being known by God. Rather every [being] is [produced] by fitting proportion according to the wisdom of the creator, being created fittingly by their logoi and by receiving being ( $\tau$ ó eival) in actuality according to themselves, because [God] exists as creator according to actuality $\left(\kappa \alpha \tau^{\prime}\right.$

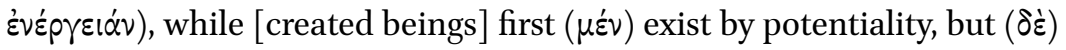
do not yet exist by actuality. Hence this is like that which is without limit ( $\tau \dot{\alpha} \alpha \ddot{\pi} \varepsilon i p o v$ ) and things which are limited ( $\tau \dot{\alpha} \pi \varepsilon \pi \varepsilon p \alpha \sigma \mu \varepsilon \dot{\varepsilon} v \alpha)$, both of which do not belong together. ${ }^{91}$

MAXImUS THE CONFESSOR, Ambiguum 7, 19,3-12 (Constas; PG 91: 1081A-B)

One finds here the same emphasis by Maximus as in Philoponus: on (a) God's

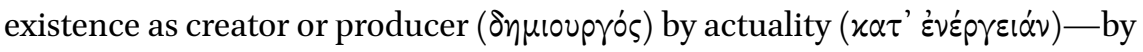
implication eternally, and not at some fixed point in time; ${ }^{92}$ yet on (b) God's thinking the logoi ( $\gamma\left(\gamma v \omega^{\prime} \sigma \kappa \varepsilon v \nu, \gamma v \omega \sigma \theta^{\prime} \nu \alpha l\right)$ as not necessitating the eternal production of created beings (as we saw above); and on (c) creatures' mode of existence as explaining how they do not have an eternal existence in the way that the logoi in God do. ${ }^{93}$ One can also see this latter case with Maximus' position that the ousia of created beings is conditioned by place and time: in effect it is essentially impossible for created beings to co-exist with God. In our passage above, one sees the inverse case: that God's thinking and possession of the logoi in eternity does not result in the necessary production of created beings simply because there is an ontological disjunction between the nature of the logoi in God and created beings in their ousia.

91 The analogy is respectively supposed to stand for God (i.e. 'that which is without limit'/ $\ddot{\alpha} \pi \varepsilon ı \rho \vee$ ) and creatures (i.e. 'things which are limited'/ $/ \dot{\alpha} \pi \varepsilon \pi \varepsilon \rho \alpha \sigma \mu \varepsilon \dot{\varepsilon} \alpha)$ : due to their respective categories of being, both 'do not belong together'.

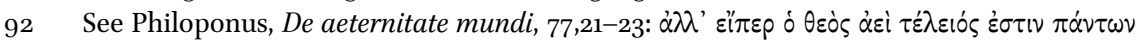

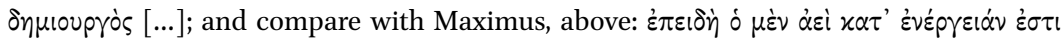

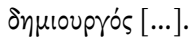

E.g. Philoponus, De aeternitate mundi, 79,9-14 and 77,1-5. 
Nonetheless, one notable difference is Maximus' two-sided distinction for the Logos (1) as beyond every predication and all being, and (2) as positively identified with the logoi of all created beings. By contrast, Philoponus does not posit an explicit distinction between God and the logoi in God: rather Philoponus seems to speak of God in terms similar to an Aristotelian conception of the divine intellect, where the logoi are thoughts in the mind of God. On the one hand Philoponus also implicitly affirms (1) when he asserts that God

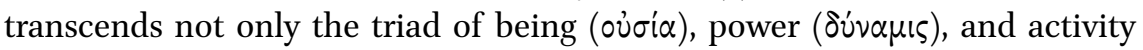

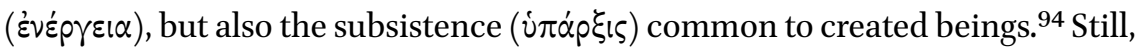
the emphasis on God's transcendence in Maximus suggests a different model for God's being than what we have in Philoponus-and in turn the logoi's relation to God's subsistence 'through Himself' ( $\delta \iota^{\prime}$ ' $\left.\alpha u v \tau o \dot{v}\right) .{ }^{95}$ Although the difference between (1) and (2) might be nominal for Maximus, the contrast to Philoponus is more striking when we look at Maximus' Capita Theologica et OEcumenica (I.48-50), which demarcates an ontological distinction between the two domains of (1) and (2): ${ }^{96}$

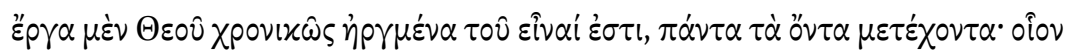

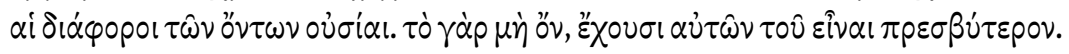

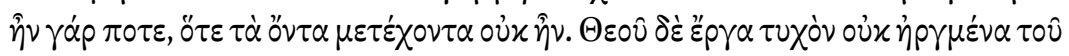

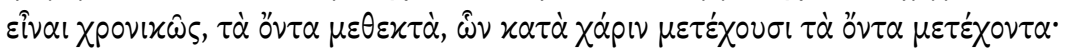

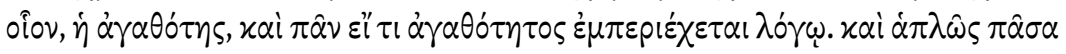

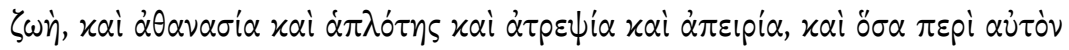

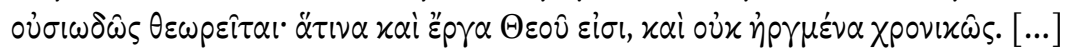

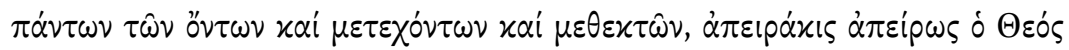

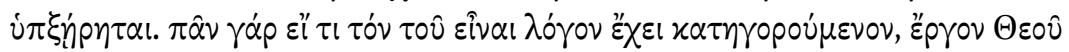
$\tau u \gamma \chi \alpha ́ v \varepsilon เ$.

The works of God which began to be in time are all participating beings, namely the differing essences of beings. For they have non-being prior to their own being: God was at some point when beings which participate were not. But the works of God which did not happen to begin to

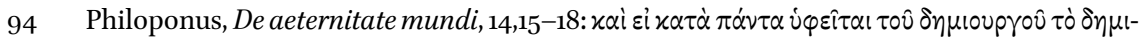

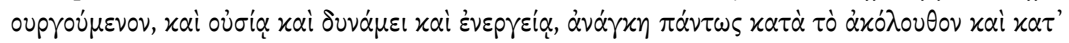
$\alpha \dot{v} \tau \dot{\eta} \nu \dot{v} \varphi \varepsilon \hat{\sigma} \sigma \theta \alpha \mathrm{l} \tau \dot{\eta} \nu \tilde{u} \pi \alpha \rho \xi I \nu$ ("And if what is created is in all respects inferior to its creatorin substance ( $0 \dot{\sigma} i^{\prime} \alpha$ ), in power, and in activity—it certainly must also be as a consequence inferior in its very subsistence ( $\tilde{\pi} \alpha \rho \xi(\nu) "$ - trans. Share, modified).

95 Cf. above, p. 13 .

96 I analyze this passage in depth in Greig 2017, where I argue that Maximus appropriates Proclus' three-fold participation framework from The Elements of Theology, Prop. 23-24. 
be in time are participated beings, which participating beings partake according to grace: just as with goodness, and everything of goodness if it is embraced by account. And simply all life, immortality, simplicity, immutability, and infinity; such things are contemplated in an essential way around him. Those are also works of God, and they did not begin in time. [...] God transcends all beings infinitely times without number ( $\dot{\alpha} \pi \varepsilon i \rho \dot{\alpha} x\llcorner\varsigma \dot{\alpha} \pi \varepsilon i \rho \omega \varsigma)$-both those which are participated and those which participate. For if everything has the account of being predicated [of it], it happens to be a work of God. ${ }^{97}$

MAXIMUS THE CONFESSOR, Captita Theologica et OEcumenica I,48-49 (PG 90: 1100C-1101A)

Maximus draws a distinction here between (1) works ( which began in time; (2) works of God, or 'beings', which are outside time; and (3) God in Himself, who transcends both kinds of 'works'. One can detect in this an appropriation of Proclus' three-fold distinction between the unparticipated, participated, and the participant from The Elements of Theology, Prop. 23, which corresponds with Maximus' distinctions between God in Himself, God's timeless works, and God's created works in time. ${ }^{98}$ We find a mediated notion of participation here inasmuch as God in Himself (3) remains transcendent throughout the process of participation, while created beings still participate in God via God's timeless works (2).${ }^{99}$ Given Maximus' understanding of the logoi, it seems clear that Maximus has the logoi in mind with the timeless works (2), especially when he implies that the timeless works are those by which created beings in time derive their being. ${ }^{100}$ This would also go along with Maximus'

97 Cf. Origen, On First Principles 3.5.3, who claims that God did not cease from his works despite his creation of the world; yet contrary to this passage, Origen uses this claim as part of his position that there has been an eternal cycle of creations by God. One can then see this passage in Maximus as part of a larger whole both appropriating, and responding to, Origen - while using Philoponus' anti-eternalist arguments in doing so. See MuellerJourdan 2015a for an overview of Origen's background in Maximus' framework.

98 Cf. Greig 2017, p. 139-142.

99 Indeed we find places later in the Capt. Th. where Maximus identifies God with the types of timeless works he mentions in I.48: e.g. in I.54 (PG 90: 1104B) Maximus states that the terms 'life' and 'being' apply most properly to God, and in turn one's complete participa-

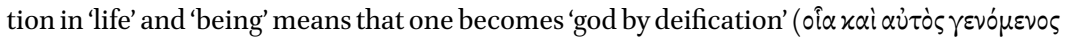

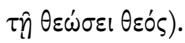

100 See e.g. Maximus, Capt. Th. I.5O (PG 90:1101B), in the context of the virtues which pre-exist

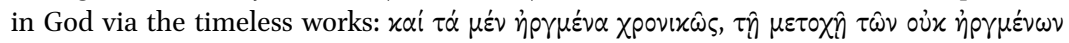

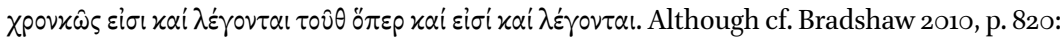
"One can contrast the logoi in this respect with the 'things around God' discussed earlier. 
language of the logoi as eternally pre-contained in God, while God's possession of the logoi does not necessitate the eternal existence of created beings.

Ultimately this suggests a modified picture of Philoponus' framework that Maximus adopts, which as we saw earlier did not imply the kind of distinction we find in Capita Th. I.48-50, above: namely between God as unparticipated and the participated 'works' outside time-implicitly the logoi. That Maximus accepts this distinction suggests an implicit response to the difficulty we saw in Philoponus, where Maximus affirms the need for an ontological distinction in God while respecting that the participated 'works' are not separate entities from God but are still essentially related, or identified with, God. As we will see, Maximus ends up modifying one transformation of Proclus with another transformation of Proclus-via Dionysius the Pseudo-Areopagite.

Proclus Mediated in Dionysius the Ps.-Areopagite:The Distinction between Divine Processions and the One, Unparticipated God

Maximus directly cites Dionysius the Pseudo-Areopagite - or rather 'Dionysius' himself, the follower of St. Paul—in Ambiguum 7 when he interprets the logoi as 'divine wills' $\left(\theta \varepsilon i \alpha \theta \varepsilon \lambda \eta \eta^{\prime} \mu \alpha \tau \alpha\right),{ }^{101}$ which suggests that Maximus sees the logoi in light of Dionysius' understanding of the 'divine wills', or 'processions' ( $\pi$ póodol) of God into beings. How Dionysius understands the 'processions' differs from the way Philoponus understands the logoi in God: the divine processions are distinct from God considered in Himself, who transcends the processions as well as the created effects of the processions-yet God is also identified with the processions themselves. We see this elaborated in Maximus' citation, which clarifies how God pre-contains the paradigmatic causes of all things in Himself rather than in virtue of separate causes or principles:

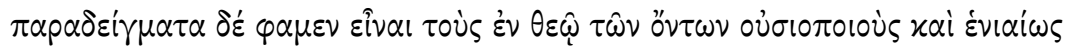

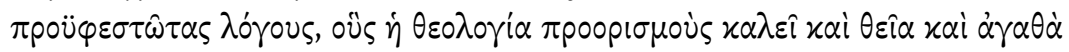

God presumably does not choose to be, to live, to be wise, and so on, although He does choose the particular ways in which these attributes are expressed. It seems, then, that both the 'things around God' and the logoi are divine acts of self-manifestation, but the former would belong to God even apart from the creative act, whereas the latter would not." However from what we have seen above, even the logoi would seem to belong to God eternally apart from the creative act (pace Bradshaw): see earlier, Ambiguum 7, 19,3-12 (PG 91: 1081A-B).

101 Cf. earlier n. 46. 


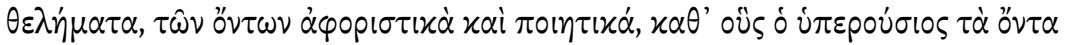

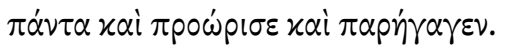

But we say that the paradigms [of beings] are the being-producing and

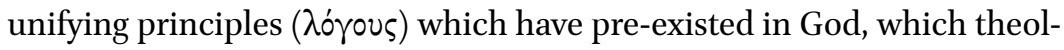
ogy calls both divine pre-determinations and good wills, which are delimiting and productive of beings, according to which what is beyond being ( $\delta$ i $\pi \varepsilon p o v ́ \sigma 10 \varsigma$ ) both pre-determines and produces all beings. ${ }^{102}$

DiONYSIUS THE PS.-AREOPAGITE, De divinis nominibus v.8, 188,6-10

Here, Dionysius ties the distinct paradigmatic causes of beings to God as the sole agent of causation. Just before this passage, Dionysius points out how the sun embodies within itself a plurality of effects that it distinctly brings about in sub-lunar beings—-such as existence, growth, life, and so on: ${ }^{103}$ this helps show how God analogically pre-contains the varying effects of created beings to a greater degree as their cause. ${ }^{104}$ This also comes after Dionysius earlier shows how the differing kinds of beings do not lead to a plurality of causes, but rather to the fact that there must be one cause in which the plurality of causes coincide. One sees this in the well-known passage from De divinis nominibus V.2, where Dionysius shows that "the Good is not one thing ( $\left.\alpha \lambda_{0}\right)$ and Being another $\left(\alpha \lambda_{0}\right)$ and Life or Wisdom another ( $\left.\alpha \lambda_{0}\right)$, nor that the causes are many and that there are different divinities, higher and lower, productive of different things; but that the entirely good processions and divine names hymned by us are of one God (Evòs $\theta \varepsilon \circ \hat{v})$.". 105

One can recognize Dionysius' implicit anti-polytheist position here among other passages, ${ }^{106}$ where he collapses what were a hierarchy of distinct causes, held by previous pagan Platonists like Proclus, into one God. ${ }^{107}$ This is made

102 Cf. Perl 2010, p. 771-772. and in this volume Vlad's contribution, p. 101, for further discussion of this passage. See also Brown 2012, (esp. p. 227-230) for an overview of Dionysius framework.

103 Dionysius the Ps.-Areopagite, De divinis nominibus v.8, 187,17-188,3.

104 One can detect here the heritage of Proclus' own formulation of this principle in The

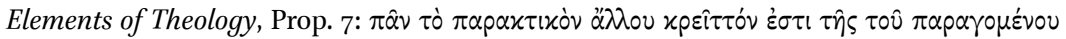
$\varphi v ं \sigma \varepsilon \omega \varsigma$ ("Every productive cause is greater than the nature of its product"). For a discussion of this principle, see Lloyd 1976 and Greig 2021, p. 79-9o.

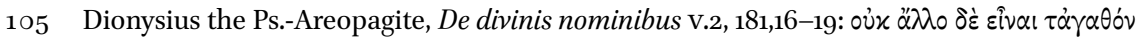

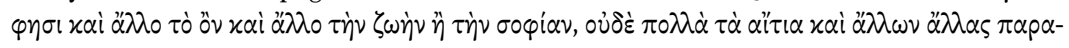

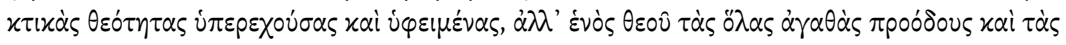
$\pi \alpha \rho^{\prime} \dot{\eta} \mu \omega \hat{~} \varepsilon^{\prime} \xi u \mu \nu 0 v \mu \varepsilon^{\prime} v \alpha \varsigma \theta \varepsilon \omega v \nu \mu i \alpha \varsigma$. Cf. in this volume Vlad's contribution, p. 105-107.

106 See e.g. Dionysius the Ps.-Areopagite, De divinis nominibus XI.6.

107 A point especially emphasized in Gersh 1978, p. 164-165. We also already saw this implic- 
clear after our previous passage when Dionysius next says that "one [procession $]^{108}$ is revealing of the complete providence of the one God, and the other [processions], his more universal ( $\delta \lambda \iota x \omega \tau \varepsilon \dot{\varepsilon} \rho \omega \nu)$ and more particular ( $\mu \varepsilon \rho i \varkappa \omega \tau \dot{\varepsilon}-$ $\rho \omega v)$ [providences]."109 On the one hand, the fact that the processions come from the same source implies that there is no true 'higher' or 'lower' principle corresponding to higher and lower kinds of effects. At the same time, Dionysius' references to different processions as 'more universal' ( $\dot{\lambda} \lambda \omega \omega \tau \tau \varepsilon \dot{\varepsilon} \omega \nu)$ and 'more particular' ( $\mu \varepsilon p i \varkappa \omega \tau \varepsilon \dot{\varepsilon} \rho \omega \nu)$ suggests that they pre-contain the hierarchical structure of reality that they produce by their causality $\left(\kappa \alpha \tau^{\prime} \alpha i \tau i \alpha \nu\right)$. This comes out in Dionysius' language of God as the cause of being and life in all things, such that He is "the life of living things and being of beings" ( $\dot{\eta} \tau \hat{\omega} \nu$

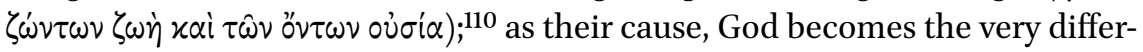
entiation by which creatures are distinct in their being — and at once the cause of creatures' identity and unity - while yet remaining the same and undifferentiated in Himself;"111 and so on. We can make sense of this language in light of Dionysius' language of God pre-containing the paradigms ( $\pi \alpha \rho \alpha \delta \varepsilon i \gamma \mu \alpha \tau \alpha)$ of beings in Himself: God perfectly embodies the features seen in produced beings while yet remaining transcendent. Although the principles contained in God lack the corresponding hierarchical ordering found in their corresponding effects-since they are identified with God in Himself-they nevertheless anticipate the distinct, hierarchical characters that are manifested.

In surveying Dionysius' notion of God's processions in light of his simultaneous affirmation of God's transcendence, Proclus' framework will be important to better understand Dionysius' own framework. Certain scholars ${ }^{12}$ have noted that Dionysius' attribution of positive and negative features to Godindicating both the $\pi \alpha \rho \alpha \delta \varepsilon i \gamma \mu \alpha \tau \alpha$ that exist immanently in God, and God's absolute transcendence over beings_-implies a collapse of the first and second hypotheses of Plato's Parmenides, which for Proclus and other Neoplatonists indicate distinct sets of principles: the first hypothesis as indicating the first cause, totally removed from all beings, and the second hypothesis as indicating the subordinate principles of Being and Intellect, which contain the posi-

itly in Philoponus' emphasis that God is the creator of beings 'without any intermediary' ( $\dot{\mu} \mu \dot{\varepsilon} \sigma \omega \varsigma)$ : cf. above, n. 74 .

108 In this context, the procession, or name, of the Good: see Dionysius the Ps.-Areopagite, $D e$ divinis nominibus V.2, 181,1-3.

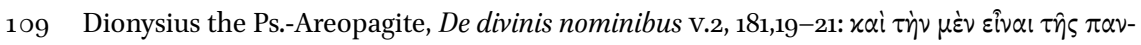

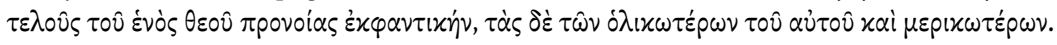

110 Dionysius the Ps.-Areopagite, De divinis nominibus, I.3, 112,4.

111 Dionysius the Ps.-Areopagite, De divinis nominibus, IX.5, 210,7-11; 211,10-12.

112 Among others, see Wear, Dillon 2007, p. 15-16, Gersh 1978, p. 155-156, and Lilla 1997. 
tive features of Being. On this reading, God is straightforwardly identified with Intellect, or rather Being (for Proclus), as well as the One, insofar as the negative and positive attributes of both hypotheses would apply to God. ${ }^{113}$ While affirming the latter, another, more refined reading of this transformation would be to look rather at Proclus' theory of the henads behind Dionysius' discussion of God and the divine processions: although doing away with the real distinction implied in Proclus' henads, considered as separate gods (and hence separate 'principles' or 'causes'), Dionysius' conception of God would then still admit some form of distinction, similar to that between the One and the henads.

For Proclus the henads are the participated counterparts of the One, which is prior to the henads as unparticipated, ${ }^{114}$ while the One and the henads both share the same essential nature as purely 'one'115 and as beyond beings characterized by plurality and differentiation. ${ }^{116}$ The henads are posited to explain the different, specific kinds of plurality and unity found in the various classes of beings, ${ }^{117}$ such that they are responsible for both universal characteristics (pertaining to Being and Intellect) and also particulars and individuality. ${ }^{118}$ Because the henads are the correlating causes of the different classes of Being, it is in this light that Proclus classifies the henads as falling under the Parmenides' second hypothesis, rather than the first hypothesis, where the negative attributes of the latter pertain properly only to the One. ${ }^{119}$ Proclus then has an implicit twofold reading of the second hypothesis: although it describes Being, properly speaking, it also pertains more to the henads as the direct causes of the distinct positive affirmations pertaining to Being. Thus, just as for Dionysius' God, the negative and positive attributes of both hypotheses apply to the henads: they act as intermediaries between the negative attributes of the first hypothesis (which pertain to the One) and the positive attributes of the second hypothesis (which pertain to Being).

113 This also seems to be the position of Vlad in this volume (esp. p. 108).

114 Proclus, The Elements of Theology, Prop. 116: see esp. 102,14-16, where the main distinction marking the One off from the henads is the latter's causality of particular things, and not

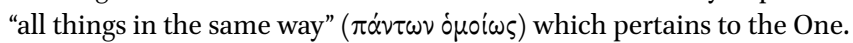

115 See e.g. Proclus, The Elements of Theology, Prop. $113,116$.

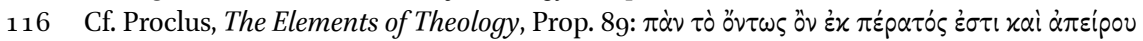
("All true being is derived from Limit and Unlimited.")

117 An example of this can be seen in Proclus, The Elements of Theology, Prop. 151-159, where the henads are classed according to the various attributes manifested in the realm of Being, up to the highest classes of Limit and Unlimited.

118 For further analysis on Proclus' view of henads as principles of individuality and unity, see Butler 2005.

119 Proclus, In Parmenidem, 1062,14-1063,1 (Steel). 
Similarly, Proclus' characterization of the henads as equally 'one' in the same sense as the One-itself, while distinct from each other-and the One-merely according to their distinct effects, is similarly reflected in Dionysius' characterization of God as one and simultaneously many through the distinct processions. As Proclus mentions in The Elements of Theology, Prop. 116, each henad differs from the One by its existence ( $\dot{\tau} \pi \dot{\sigma} \sigma \tau \alpha \sigma i \varsigma$ ) as 'something other than unity'

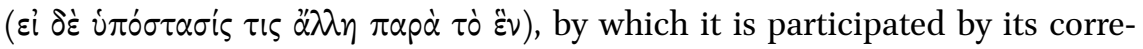

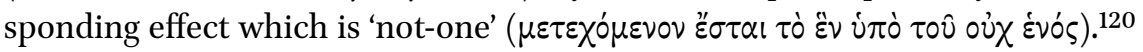
In the Parmenides Commentary, Proclus elaborates on this sense of 'something

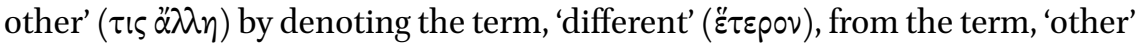
$(\alpha \lambda \lambda \eta)$, in the case of the henads: although the 'Many' ( $\tau \dot{\alpha} \pi \circ \lambda \lambda \dot{\alpha})$-implicitly

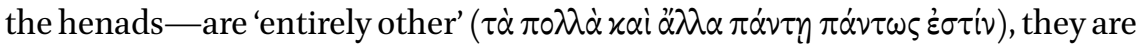

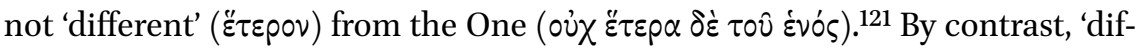

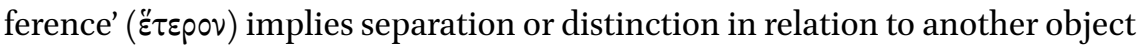
or entity - what characterizes the realm of Being; this would be in contrast to what is purely 'other', which does not imply such separation, as for the henads. This sense of being 'other' makes sense of how Proclus can understand the

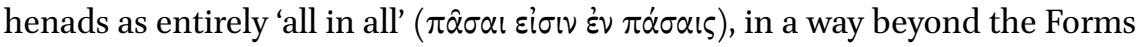
or principles of Being, ${ }^{122}$ while they are simultaneously autonomous and distinct from each other and, in turn, the One. Hence, while each henad's causal activity is distinct, each henad is reflective of all others by virtue of the unity shared in all the henads which is ultimately derived from the One.

As Timothy Riggs has noted, Dionysius' language for the Trinity is strikingly similar to Proclus' terminology for the henads, inasmuch as both the members of the Trinity and the henads are described as 'all in all' (for Proclus) or 'wholes

\footnotetext{
120 Proclus, The Elements of Theology, Prop. 116, 102,22-23.

121 Proclus, In Parmenidem, 119o,4-16. Cf. Butler 2005's discussion esp. in p. 92-93; cf. Riggs 2011, p. 72-73.

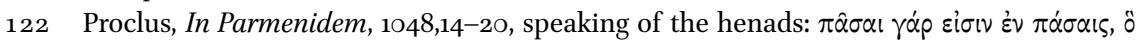

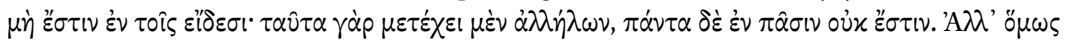

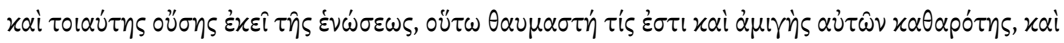

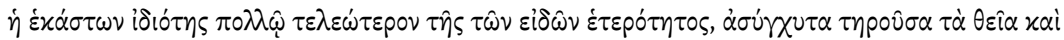

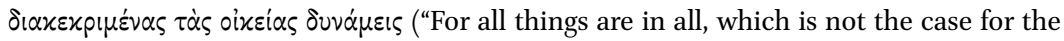
Forms: for these participate each other, yet all things are not in all. But in the same way, since there is such a degree of unity ( $\dot{\varepsilon} \omega \dot{\omega} \sigma \omega \varsigma)$ up there, how marvelous and unmixed

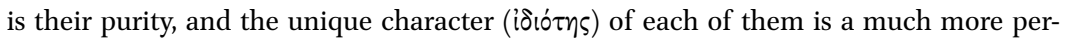
fect thing than the otherness of the Forms, preserving unconfused the divine entities and their proper powers as differentiated.") Cf. The Elements of Theology, Prop. 103 where Proclus qualifiedly applies the phrase, 'all things in all', to the triadic principles of Being, Life, and Intellect—although in the mode of each principle's existence (92,13: $\pi \dot{\alpha} \nu \tau \alpha \dot{\varepsilon} \nu \pi \hat{\alpha} \sigma \mathrm{v}$,

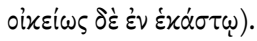


in wholes' (for Dionysius) in an unqualified way. ${ }^{123}$ In the same way, this would also similarly describe Dionysius's language for the divine processions, again similar to Proclus' description of the heands. Although Dionysius emphasizes God as the sole cause of all the distinct effects of being, passages such as $D e$ divinis nominibus XI.6 imply distinct 'powers' in God, both corresponding to the various, distinct effects in creatures, and the means by which God is participated:

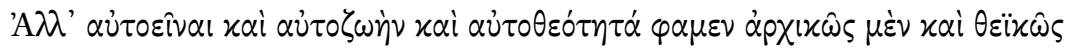

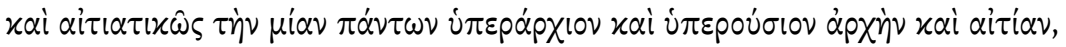

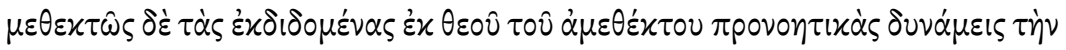

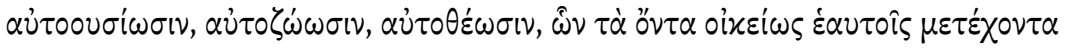

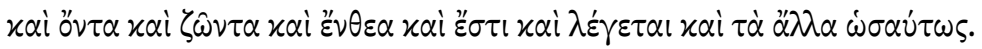

But we speak of Being-itself, Life-itself, and Divinity-itself in the manner of a first principle ( $\dot{\alpha} \rho \chi i \kappa \omega \hat{\omega} \varsigma)$, in a divine manner ( $\theta \varepsilon \ddot{x} x \hat{\omega} \varsigma)$, and in a causal manner ( $\alpha i \tau i \alpha \tau \kappa \omega \hat{\omega})$ as the one principle and cause beyond-

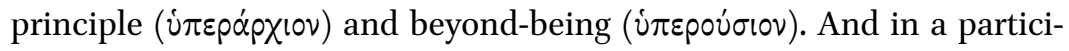
pated way [we speak of] the gifts given as providential powers from God, who is unparticipated, as Essentializing-itself ( $\alpha \dot{\tau} \tau 00 v \sigma i \omega \sigma v)$, Animatingitself ( $\alpha \dot{\tau} \tau 0 \zeta \dot{\omega} \omega \sigma \nu)$, and Divinizing-itself ( $\alpha \dot{\tau} \tau 0 \theta \dot{\varepsilon} \omega \sigma \nu v)$, of which participating beings are and are properly called beings, living beings, divinized beings, and the others $(\tau \dot{\alpha} \dot{\alpha} \lambda \lambda \alpha)$ in the same way by these [providential powers].

Dionysius the PS.-AREOPAGITE, De divinis nominibus, XI.6, 222,13-223,1.

One can already recognize the main influence behind Maximus' distinctions for God in Capt. Th. I.48-5o above: we find a similar distinction in Dionysius

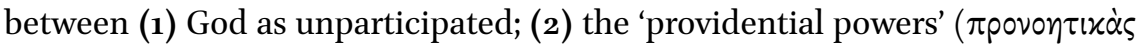

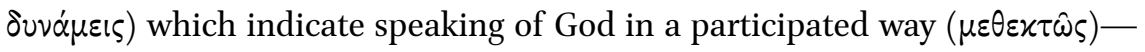

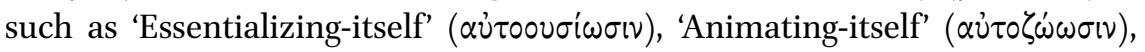
and 'Divinizing-itself' ( $\alpha \dot{\tau} \tau 0 \theta \varepsilon \dot{\varepsilon} \omega \sigma \nu)$; and (3) the participants, which are correspondingly called beings (

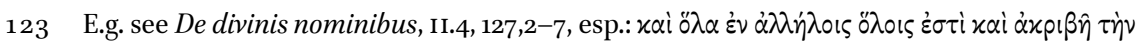

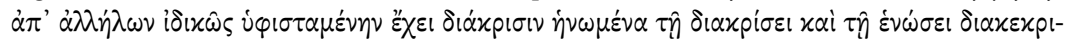
$\mu \varepsilon \dot{v} \alpha$ ("[The hypostases—scil. of the Trinity] are wholes in the wholes of each other in an unmixed and precise way hold their distinction standing their ground individually from each other, being unified in separation and separated in union"- trans. Riggs). See Riggs 2011 (esp. p. 75-76., and p. 75, n. 16), and Riggs 2010, p. 117-118. 
( $(v \vee \theta \varepsilon \alpha)$, in virtue of the latter category (2). It is notable that Dionysius speaks of a plurality of powers within God-while God remains unparticipated in Himself, despite also being participated through the powers. ${ }^{124}$ Dionysius also notably does not refer providence to God, considered as unparticipated, but rather to the 'powers' given out by God. This suggests, on the one hand, that the function of providence, and even of causality, is externalized — or rather distinguished from God when considered by Himself.

Once again, Dionysius' distinction mirrors Proclus' own between the One and the henads, insofar as the One, in its capacity as unparticipated, delegates causal power to the henads, which in turn each possess and exercise providence according to their own subsistence ( $ं \pi \dot{\alpha} p \xi ı)$ ). ${ }^{125}$ This, in turn, reflects Proclus' doctrine of participation from The Elements of Theology, Prop. 23, which similarly uses the language of 'giving' ( $\delta \omega \sigma \varepsilon ı)$, as seen above in Dionysius, for the unparticipated monad producing participated entities by which beings may participate in its shared, characteristic property: ${ }^{126}$ hence, the One also 'gives' out the henads as providential entities by which its unity is distributed among all beings. ${ }^{127}$ Taking this together with Proclus' description of the henads as

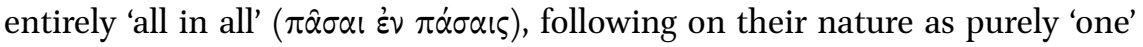
like the One-itself, one can see the analogy to Dionysius: God in his own being remains unparticipated and separate from all beings, yet the 'providential powers' which are given by God, and participated by all beings, are also 'God' in the same sense, albeit God as participated in specific respects. For both Dionysius

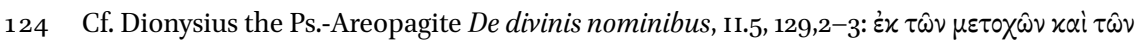

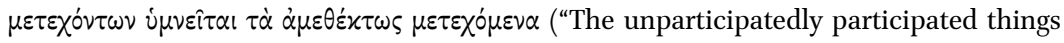
[i.e. belonging to God] are hymed from the participations and participants").

125 Compare with Proclus, The Elements of Theology, 120, 104,31-32, where the gods possess

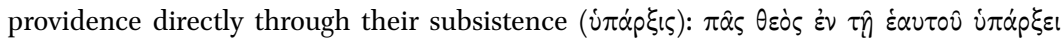

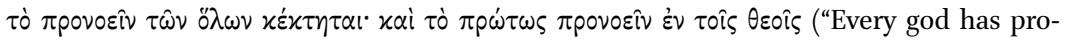
cured in its subsistence providence of the universe: and primary providence is in the gods").

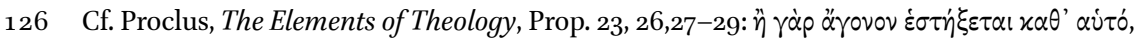

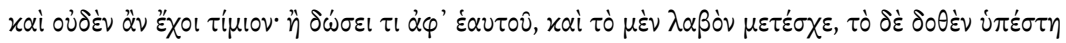
$\mu \varepsilon \tau \varepsilon \chi 0 \mu \varepsilon \dot{\varepsilon} \omega \varsigma$ ("For either [the unparticipated] will be established as unproductive by itself, and it would then have no honor; or, it will give something from itself, and that which receives participates, while what is given is brought to existence in a participated way").

127 Although with an important qualification: unlike the relation of unparticipated/partici-

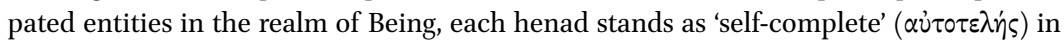
relation to the One and each other (cf. e.g. Proclus, The Elements of Theology, Prop. 114, 131): therefore, they are not 'derived' from the One, like other participated members from their respective unparticipated monads (e.g. many, participated intellects derived from unparticipated Intellect-itself; etc.), insofar as they are autonomous principles. On this see Butler 2005, p. 97-98, and Greig 2021, p. 193-197. 
and Proclus, then, there is no inherent distinction or difference when at the level of the henads, for Proclus, or God and the participated powers, for Dionysius. ${ }^{128}$

Yet given these direct parallels so far indicated, it is also important to balance this with the specific kind of rejection of Proclus' framework given by Dionysius. For one, Proclus maintains in various places that the henads are also 'first principles' ( $\dot{\alpha} p \chi \alpha i)$ in exactly the same sense as the One:129 one then has to admit a plurality of principles ( $\dot{\alpha} p \times \alpha i)$, rather than Dionysius' God as 'the

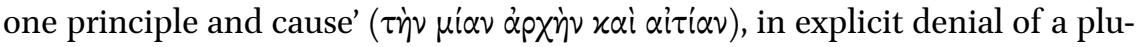
rality of principles. Further if we look more closely at Dionysius' denial that the distinct processions differ from God, the parallels in language to Proclus' henads are striking. In particular, Dionysius denies that the causes of 'other things' ( $\alpha \lambda \omega \nu)$ are themselves 'other' ( $\alpha^{2} \lambda \mathrm{O}$ ) in De divinis nominibus V.2 ${ }^{130}$ reminiscent of the way that Proclus refers to the henads, or gods, as 'other'

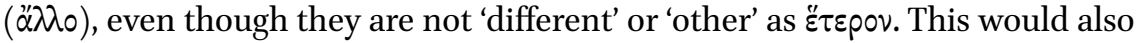
follow from Proclus' affirmation that the henads are 'self-complete' ( $\alpha \dot{\tau} \tau 0 \tau \varepsilon \lambda \eta \dot{\zeta} \varsigma$ ), which is how they are both linked to the One, mirroring the One's pure unity, and simultaneously distinct (as 'other' $/ \alpha \lambda \lambda_{0}$ ) from the One and each other. ${ }^{131}$ By contrast, Dionysius denies that the participated processions, or 'providential powers' of De divinis nominibus XI.6 above, are distinct or 'self-complete' in Proclus' sense-specifically as implying separate agency apart from the one God.

Hence, how Dionysius's distinction can be represented between the divine processions and God in Himself becomes somewhat tricky: on the one hand, the divine processions appear as distinct quasi-principles-as 'Being-itself', 'Life-itself', and so on - but they are directly identified with God, hence undifferentiated from God in their numerical identity, while God remains 'unpar-

128 Cf. Lilla 199o's comparison of Dionysius to Proclus and previous Platonists in p. 48-50. Although whereas Lilla interprets the procession of Being in Dionysius to the principle, Being, in Proclus (p. 49), I suggest here that Dionysius may be considering these processions in light of the henads that correspond to the order of Being, similar to Riggs' interpretation of the Trinity in Dionysius.

129 Cf. Proclus, In Parmenidem, 1048,1-5.

130 Cf. above p. 150-152, incl. n. 107.

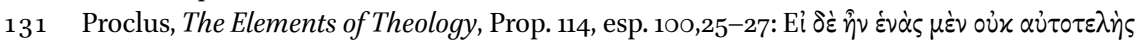

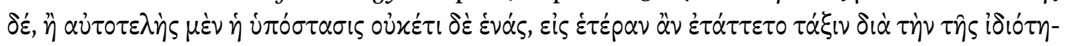
$\tau \circ \varsigma \dot{\xi} \xi \alpha \lambda \alpha \gamma \eta \dot{\eta} \nu$ ("If it were a henad but not self-complete, or self-complete but its existence were not a henad, it would be assigned to a different order in virtue of the variance from its [divine] character"). 


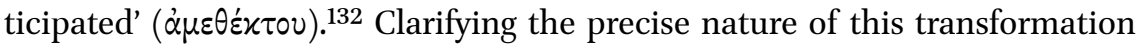
lies beyond the scope of this article, ${ }^{133}$ but for now we may make the following brief conclusion. Dionysius's appropriation of Proclus' framework for the One and the henads suggests a more nuanced rejection of polytheism by Dionysius: it is not so much Proclus' entire framework behind the henads (or 'henadology') that Dionysius denies, but rather the respect in which each distinct divine procession-manifesting as 'Being-itself', 'Life-itself', and so on-is distinct and considered to be 'divine', either as a separate agent (in Proclus) or as one, individuated aspect of the one God (in Dionysius). What Dionysius preserves from Proclus, however, is the idea that the first principle cannot be participated in an unqualified way — as unparticipated — but can only be participated under certain, distinct aspects, which are manifested and 'given' as distinct powers in relation to the participants.

\section{Assessing Maximus' Appropriation of Proclus in Dionysius the Ps.-Areopagite}

Returning to Maximus, we can already see a number of areas where Maximus inherits aspects of Proclus' distinction between the One and henads through Dionysius' transformation. We saw above how the logoi in Ambiguum 7 go together with the 'works of God' ('́pүá $\theta \varepsilon \circ \hat{v})$ outside time from Ch. Theol. I.48$5^{\circ}$, where these 'works' are differentiated from God in Himself, who remains implicitly unparticipated. ${ }^{134}$ As we saw, the passage finds its provenance in

132 Cf. above, Dionysius the Ps.-Areopagite De divinis nominibus, XI.6, 222,16.

133 Many, various interpretations have been given to this transformation by Dionysius the Ps.-Areopagite. See among others, D'Ancona 1996, p. 366-367, maintaining that Dionysius ultimately returns to a Plotinian notion of the One with God, via Proclus' henads: "As with the Proclean Henads, the Dionysian God is everywhere by means of his providence, and his capacity to "comprehend" in himself all the lower entities is qualified by his transcendence." Gersh 1978, p. 165-166 holds that Dionysius the (Ps.)-Areopagite and his successors simply maintain the tension of God's transcendence and immanent identification with the triad, Being-Life-Intellect, critiquing (in p. 166, n. 184) attempts by those like Lossky 1957 to interpret God and the processions in light of Gregory Palamas' distinction between

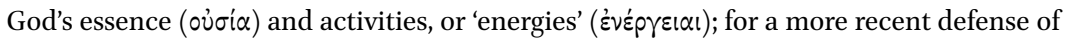
this interpretation, see Jones 2005, p. 390-391. For a survey of Proclus' transformation in the later Byzantine, Latin, and Arabic worlds, see Adamson, Karfik 2017, esp. p. 292-301, and the contributions in Gersh 2014.

134 Although it is noticeable that, unlike Dionysius the Ps.-Areopagite, Maximus does not explicitly say that God is 'unparticipated' ( $\alpha \mu \varepsilon \theta \varepsilon \dot{\varepsilon} \kappa(0)$ ); instead in Capt. Th. I.49 (PG 90: 1101A), he posits God as 'infinitely times without number' ( $\dot{\alpha} \pi \varepsilon ı \alpha$ ' $x \iota \varsigma$ $\alpha \varepsilon \varepsilon i \rho \omega \varsigma)$ transcend- 
Dionysius' De divinis nominibus XI.6, where Dionysius also distinguishes between God as unparticipated and the participated 'providential powers'. We also find the same phrasing in both figures, where participants 'are and are

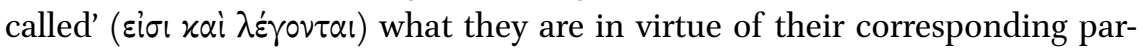
ticipated entities: in Maximus, the 'works' which have no beginning in time $(\tau \hat{\eta}$

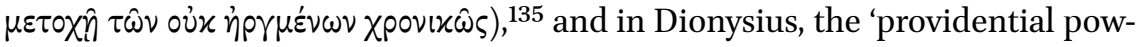

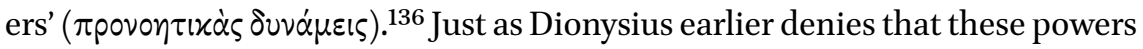
cannot be distinct in the way that Proclus' henads are, as 'self-complete' ( 2 ivo$\tau \varepsilon \lambda \eta \dot{s}$ ), Maximus similarly affirms that only the works of God in time have their own, self-determined activity, unlike the timeless works from which God does not cease. ${ }^{137}$ Although Maximus calls God's timeless works 'participated beings' ( $\tau \dot{\alpha}$ oै $v \tau \alpha \mu \varepsilon \theta \varepsilon \kappa \tau \dot{\alpha})$-as if they were self-subsistent entities-they do not differ from God, especially in Maximus' language where they are perceived 'essen-

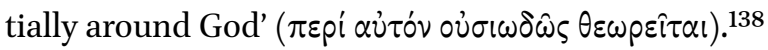

Overall, one general difference from Dionysius is that Maximus makes time the differentiating marker between God and created beings in a much stronger way than one finds in De divinis nominibus xi.6. The reason for God's transcendence over created beings subtly but importantly changes when we look at Maximus in relation to Dionysius: for Maximus the predicate, 'being', implies being conditioned by time and place, as we have seen, whereas God is unconditioned and prior to created beings. When we look at the two types of divine 'works' from Capt. Th. I.48-50, God necessarily transcends both the works in time-i.e. created beings - and the works outside time-i.e. the perfections of Being, Immortality, Life, and so on - since both have the predicate of 'being' ( $o v / \sigma^{\prime} v \tau \alpha$ ). On the one hand it would be odd for Maximus to say that God's timeless works are 'beings' in this sense, if they are outside time while the notion of 'being' implies time. Another way to understand the timeless works having the

ing both the participated, timeless 'works' and the participating 'works' in time. Cf. Greig 2017, p. 140, n. 7.

135 Maximus, Capt. Th. I.5O, PG 90: 1101B.

136 Dionysius the Ps.-Areopagite, De divinis nominibus XI.6, $222,16$.

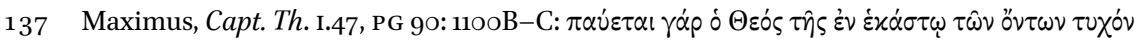

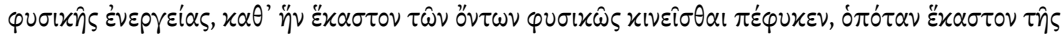

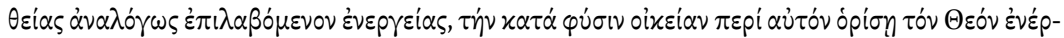
$\gamma \varepsilon \iota \alpha \nu$ ("God rests from his natural activity which happens to be in each being, according to which each of them has been disposed to move naturally whensoever each being, having obtained the divine activity in an analogous way [scil. to their being], determines about itself the activity according to their proper nature in relation to God"). Cf. Greig 2017, p. $146-147$, and n. 24.

138 Cf. above, p. 147-149. 
predicate of 'being' is that they are coordinated with the created works in time: thus the timeless works have the predicate of 'being' only as a result of their causal status, i.e. in making their participants correspondingly 'beings', 'living', 'immortal', etc. On this reading, Maximus would be adopting another tenet from Proclus' understanding of participation from The Elements of Theology, Prop. 23: that the intermediate, participated terms or entities are coordinated specifically with their respective participants. ${ }^{139}$ Consequently the participated terms inherit the character of their produced effect, even if they transcend the nature of their participants. Maximus' timeless works can then be understood as 'beings' in this sense: they are inherently related to their participants, as that by which God causes created beings (i.e. the works in time) — and yet because they are inherently related to their participants, they cannot be equated with God's own being. In this respect that which God transcends must include both the timeless works as well as the works in time, since God's being is unqualified by time-whereas the timeless works, although outside time, are coordinated with works in time.

The distinction would make sense of Maximus' two-sided distinction from Ambiguum 7, between the Logos considered through Himself ( $\left.\delta l^{\prime} \dot{\varepsilon} \alpha v \tau \dot{0} v\right)$ ), as

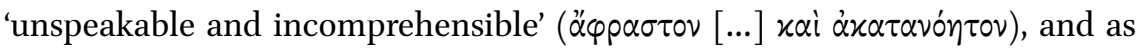

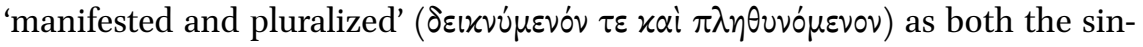
gular Logos and plural logoi. ${ }^{140}$ In this and other passages we saw Maximus speak of the logoi in such ways as pluralized 'according to the analogy of each [created being]' ( $\varkappa \alpha \tau \dot{\alpha} \tau \dot{\eta} \nu \dot{\varepsilon} x \dot{\alpha} \sigma \tau 0 u \dot{\alpha} \nu \alpha \lambda \circ \gamma(\alpha \nu),{ }^{141}$ which suggests not just that created beings receive the logoi according to their respective modes of being, but also that the logoi are made to correspond to the specific nature of their participants-in intellection, sensation, and so on. ${ }^{142}$ Once more we can see how Proclus' understanding of the henads as coordinated with their respective chain of effects in Being and beings becomes adapted in Maximus' understanding of the logoi, and, more proximately, we can see how Maximus adapts Dionysius' transformation of this with the 'providential powers' given out by God.

\footnotetext{
139 For further discussion of Prop. 23 in this passage from Maximus, cf. Greig 2017.

140 Maximus the Confessor, Ambiguum 7, 16,10-16 (PG 91: 1080A-B).

141 Maximus the Confessor, Ambiguum 7, 16,14 (PG 91: 108oB).

142 Maximus the Confessor, Ambiguum 7, 16,20-21 (PG 91: 1080B). One other, potentially relevant connection lies in Damascius and his notion of causes conducing themselves to the level of their effects: in contrast to Proclus, Damascius maintains that principles like Being, in the process of producing Intellect, take on the properties of their effect: cf. Gertz 2016.
} 
Finally, this would make sense of Maximus' discussion of providence, where God is said to know all beings by his own, characteristic 'wills' ('i $\delta \alpha \theta \varepsilon \lambda \hat{\eta} \mu \alpha \tau \alpha)$, which he equates with the logoi. ${ }^{143}$ Given where he discusses this in Ambiguum 7 , it is notable that Maximus does not refer to God knowing beings through his own being or subsistence ( $\dot{\pi} \dot{\alpha} p \xi ı \zeta)$ - as Proclus maintains for each god (i.e. henad) in The Elements of Theology, Prop. 120-but rather through his 'wills' $(\theta \varepsilon \lambda \dot{\eta} \mu \alpha \tau \alpha)$. On the one hand this implies that providence is delegated to entities external to God, and this seems suggested by Maximus' distinction between God 'through Himself' and the logoi-analogously to the One and the henads for Proclus, where the henads are the agents of providence. Yet Maximus' simultaneous identification of the logoi with God, via the Logos, suggests God knows beings through Himself, albeit under the specific aspect of his 'wills' or logoi. Along with this, Maximus maintains Proclus' position that providence transcends the kind of knowledge that pertains to intellect (vov̂) when he affirms that God comprehends particulars 'in a way prior to knowledge' ( $\pi \rho \circ \gamma \omega \omega \sigma \tau-$ $x \hat{\omega} s) .{ }^{144}$ For Proclus, this results from the henads' subsistence as unity, by which they are able to comprehend both universals and particulars, rather than by intellect which only grasps universals. Although Maximus does not state this explicitly, the same thinking obtains when Maximus shows that God's mode of knowledge is free from the constraints of created being - among which is intellect (vovs) — and that God thus knows beings as their cause.

Conclusion: Maximus' logoi as a Dynamic Synthesis of Philoponus and Dionysius the Ps.-Areopagite Founded in Proclus

Taking Maximus' use of Dionysius together with John Philoponus, we can now summarize in what way the logoi for Maximus borrow from two distinct aspects of Proclus' framework - connections one would not expect in Proclus himself, but ones which fit Maximus' purpose for understanding God within his creationist framework. With Philoponus as a mediator, Maximus inherits Pro-

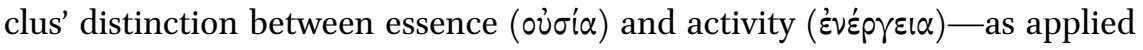
to Soul for Proclus - with his own understanding of the distinction between God's eternal possession of the logoi, and God's temporal production based on those logoi. With the way Maximus understands created being, with substance $\left(0^{\prime} \sigma^{\prime} \alpha\right)$ as limited by time and place, this sets up a sharp ontological

143 Maximus the Confessor, Ambiguum 7, 24,1-2O (PG 91: 1085A).

144 Maximus the Confessor, Ambiguum 10, 104,10-15 (PG 91: 1193A). 
divide between God and created beings, where God exists outside the delimitation of being. Yet as we saw in Philoponus, one problem with the application of the essence / activity distinction to God is that both exist throughout eternity, where God both possesses the logoi throughout eternity (correlating to ovं $\sigma^{\prime} \alpha$ ) and wills created beings' production in time within eternity (correlating to ėvép

The difficulty of articulating the distinction between God's possession and God's activity becomes one reason that Maximus employs a second feature from Proclus, through the mediation of Dionysius: the distinction between God's unparticipated being and the participated 'powers' by which creatures are created and, thereby, participate in God. Maximus thus incorporates Philoponus' understanding of the logo $i$ in God through Dionysius' framework which distinguishes between the unparticipated and participated in God. For Maximus, God then knows and creates beings not in virtue of his own being, strictly speaking, but in virtue of entities - the logoi-distinct from God's unparticipated being. Yet since God is the sole cause and principle of all beings—rather than a plurality of henads as gods, for Proclus - those entities become aspects of God: a plurality that is distinct and exists immanently 'within' God, yet distinct from God's being in Himself. While God continually possesses the logoi throughout eternity, before the creation of the world, they become principles immanently related to their produced effects: thus even God's timeless works, such as 'Being', 'Immortality', 'Life', and so on, are perfections which, while belonging essentially to God as the cause, are suited for their participants as both efficient and final causes. This ultimately fits Maximus' creationist framework for the logoi, where God distinctly possesses the logoi before bringing their effects into being - which would correspond to the two types of 'works' that he enunciates in Capt. Th. I.48-50. ${ }^{145}$

145 To what degree this solves Philoponus' problem of positing distinct volitions in God-i.e. to explain the distinction between God's eternal will, and God's specific willing in time-is not immediately clear, and lies beyond the scope of this article. An analysis of Philoponus' notion of willing in God, and its reception in Maximus and later Byzantine thinkers, is still very much a desideratum in the scholarship. One attempt to address this issue in later Byzantine thought, albeit almost entirely along patristic lines and without discussion of Philoponus, is Bradshaw 2004 (esp. p. 234-262) on St. Gregory Palamas' ontological dis-

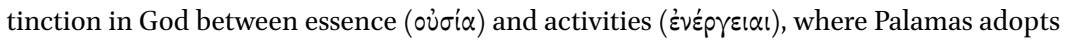
Maximus' distinction between God and the logoi (ibid., p. 238-239) for his own framework; although see Kappes et al. 2014, which outlines some of the methodological limitations of Bradshaw's approach (especially in comparing Palamas and earlier Byzantines solely with Aquinas), and suggests Duns Scotus as a more worthy Latin correlative for Palamas' framework. (Along these lines, see more recently Bradshaw 2019, which addresses the question 
Overall Proclus becomes an unexpected help for Maximus in his critique of the Origenist theory of the soul from the start of Ambiguum 7-namely the position that all souls pre-exist in the 'unit' connatural with God. Where the notion of delegated causality at the level of the first principle results in a plurality of distinct gods, for Proclus, for Maximus this results instead in immanent distinctions in God, by which God produces created beings and is participated, while preserving God's transcendence over created beings. Where the distinc-

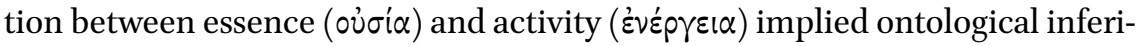
ority for Proclus, for Maximus (via Philoponus) this becomes a sign of divine perfection, indicating both God's transcendence over contingent being and the notion that creation results, not just from the activity of thinking the principles of creation throughout eternity, but through the additional operation of willing their production in time. ${ }^{146}$

\section{Bibliography}

\section{Primary Sources}

Alcinous, Albinos. Épitomé, ed. P. Louis, Paris, Les Belles Lettres, 1945.

Aristotle, Categoriae et Liber de interpretatione, ed. L. Minio-Paluello, Oxford, Clarendon Press, 1949.

Aristotle, De anima, ed. W.D. Ross, Oxford, Clarendon Press, 1956.

Damascius, Des premiers principes: apories et résolutions, ed. and tr. M.-C. Galpérine, Lagrasse, Verdier, 1987.

Diogenes Laertius, Vitae philosophorum, 2 vol., ed. H.S. Long, Oxford, Clarendon Press, 1964.

Dionysius the Ps.-Areopagite, De divinis nominibus, in Corpus Dionysiacum. I, ed. B.R. Suchla, Berlin, De Gruyter, 199o.

Gregory Nazianzen, Opera, ed. J.P. Migne (Patrologia Graeca 35-36), Paris, 1857-1858.

John Philoponus, De aeternitate mundi contra Proclum, ed. H. Rabe, Leipzig, Teubner, 1899 .

of distinction between essence and activity in God for Palamas and his successors.) It is clear from skimming current scholarship on later Byzantine thought (esp. on Palamas and his successors: for a thorough analysis of this history, see Demetracopoulos 2011), any progress can only be made with a closer analysis of Proclus' and Philoponus' reception in both early and later periods of Byzantine intellectual history.

146 Special thanks to Peter Adamson, Alan Brown, Fedor Benevich, Christophe Erismann, Evan King, and an anonymous peer reviewer for their crucially helpful feedback on early drafts and the revision of this paper. I would also like to thank with gratitude Dragos Calma, the Austrian Academy, and the European Research Council for their support 
Maximus the Confessor, Opera, ed. J.P. Migne (Patrologia Graeca 90-91), Paris, 1865.

Maximus the Confessor, On Difficulties in the Church Fathers. The Ambigua, Vol. 1, ed. and tr. N. Constas, Cambridge, MA, Harvard University Press, 2014.

Nemesius, De natura hominis, ed. M. Morani, Leipzig, Teubner, 1987.

Origen, On First Principles, Vol. 1, ed. and trans. J. Behr, Oxford, Oxford University Press, 2017.

Philo of Alexandria, Opera quae supersunt, Vol. 2, ed. P. Wendland, Berlin, Reimer, 1897.

Philo of Alexandria, Quaestiones in Genesim et in Exodum. Fragmenta Graeca, ed. F. Petit, Paris, Éditions du Cerf, 1978.

Plato, Opera, 5 vol., ed. J. Burnet, Oxford, Oxford University Press, 1900-19o7.

Plotinus, Opera, 3 vol., ed. P. Henry, H.-R. Schwyzer, Leiden, Brill, 1951-1973.

Proclus, The Elements of Theology, ed. and tr. E.R. Dodds, Oxford, Clarendon Press, 1963.

Proclus, In Platonis Parmenidem commentaria, ed. C. Steel, Oxford, Oxford University Press, 2007-2009.

Proclus, In Platonis Timaeum commentaria, ed. E. Diehl, 3 Vol., Leipzig, Teubner, 19031906.

Proclus, Tria opuscula (De providentia, libertate, malo) Latine Guilelmo de Moerbeka vertente et graece ex Isaacii Sebastocratoris aliorumque scriptis collecta, ed. H. Boese, Berlin, De Gruyter, 196o.

Proclus, Théologie platonicienne, 6 vol., ed. and tr. H.D. Saffrey, L.G. Westerink, Paris, Les Belles Lettres, 1968-1997.

Proclus, Tria opuscula, Textkritisch kommentierte Retroversion der Übersetzung Wilhelms von Moerbeke, ed. B. Strobel, Berlin/Boston, De Gruyter, 2014.

Simplicius, In Aristotelis physicorum libros octo, 2 vol., ed. H. Diehls, Leipzig, Teubner, 1882-1895.

Stoicorum Veterum Fragmenta, 4 vol., ed. H. von Arnim, Leipzig, Teubner, 1903-1924.

\section{Secondary Sources}

Adamson, P., Karfik, F. (2017), "Proclus' Legacy”, in P. d'Hoine, M. Martijn (eds), All from One: A Guide to Proclus, Oxford, Oxford University Press, p. 29o-321.

Benevich, F. (2017), "Fire and Heat: Yahyā B. 'Adī and Avicenna on the Essentiality of Being Substance or Accident", in Arabic Sciences and Philosophy 27/o2, p. 237-267.

Benevich, G. (2011), "John Philoponus and Maximus the Confessor at the Crossroads of Philosophical and Theological Thought in Late Antiquity", in Scrinium 7-8/1, p. 102130.

in the final stage of revising this article within the framework of the project, NeoplAT (ERC_CoG_771640). 
Blank, D. (2010), "Ammonius Hermeiou and His School", in L.P. Gerson (ed.), The Cambridge History of Philosophy in Late Antiquity, Cambridge, Cambridge University Press, p. 654-666.

Boys-Stones, G. (2017), Platonist Philosophy 8о BC to AD 250: An Introduction and Collection of Sources in Translation, Cambridge, Cambridge University Press.

Bradshaw, D. (2004), Aristotle East and West: Metaphysics and the Division of Christendom, Cambridge, Cambridge University Press.

Bradshaw, D. (2010), "Maximus the Confessor", in L.P. Gerson (ed.), The Cambridge History of Philosophy in Late Antiquity, Cambridge University Press, Cambridge, p. 813828.

Bradshaw, D. (2013), "The Logoi of Beings in Greek Patristic Thought", in B. Foltz, J. Chryssavgis (eds), Toward an Ecology of Transfiguration: Orthodox Christian Perspectives on Environment, Nature, and Creation, New York, Fordham University Press, p. 9-22.

Bradshaw, D. (2019), "Essence and Energies: What Kind of Distinction?", in Analogia 6, p. $5^{-35}$.

Brown, A. (2012), "Dionysius the Areopagite", in A. Casiday (ed.), The Orthodox Christian World, London / New York, Routledge, p. 226-236.

Butler, E.P.(2005), "Polytheism and Individuality in the Henadic Manifold", in Dionysius 23, p. 83-104.

Chiaradonna, R. (2014), "Substance", in S. Slaveva-Griffin, P. Remes (eds), The Routledge Handbook of Neoplatonism, Abingdon, Routledge, p. 216-23o.

Constas, M. (2017), "Maximos the Confessor, Dionysios the Areopagite, and the Transformation of Christian Neoplatonism", in Analogia 1/1/2, p. 1-12.

Cvetković, V. (2015), "The Transformation of Neoplatonic Philosophical Notions of Procession (Proodos) and Conversion (Epistrophe) in the Thought of St. Maximus the Confessor", in M. Knežević (ed.), The Ways of Byzantine Philosophy, Alhambra, Sebastian Press, p. 195-210.

D’Ancona, C. (1996), "Plotinus and Later Platonic Philosophers on the Causality of the First Principle”, in L.P. Gerson (ed.), The Cambridge Companion to Plotinus, Cambridge, Cambridge University Press, p. 356-385.

D’Ancona, C. (2011), "Platonic and Neoplatonic Terminology for Being in Arabic Translation", in Studia Graeco-Arabica 1, p. 23-46.

Demetracopoulos, J.A. (2011), "Palamas Transformed: Palamite Interpretations of the Distinction Between God's 'Essence' and 'Energies' in Late Byzantium”, in Bibliotheca 11, p. 263-372.

Dillon, J. (1997), “Damascius on Procession and Return”, in J.J. Cleary (ed.), The Perennial Tradition of Neoplatonism, Leuven, Leuven University Press, p. 369-380.

Emilsson, E.K. (2007), Plotinus on Intellect, Oxford, Clarendon Press.

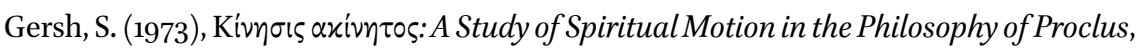
Leiden, Brill. 
Gersh, S. (1978), From Iamblichus to Eriugena: An Investigation of the Prehistory and Evolution of the Pseudo-Dionysian Tradition, Leiden, Brill.

Gersh, S. (ed.), (2014), Interpreting Proclus: From Antiquity to the Renaissance, Cambridge, Cambridge University Press.

Gertz, S. (2016), 'Knowledge, Intellect and Being in Damascius', in Doubts and Solutions Concerning First Principles", in Ancient Philosophy 36/2, p. 479-494.

Greig, J. (2017), “Proclus' Doctrine of Participation in Maximus the Confessor's Centuries of Theology I.48-50", in M. Vinzent (ed.), Studia Patristica LXXV: Papers presented at the Seventeenth International Conference on Patristic Studies held in Oxford 2015, p. 137-148, Leuven, Peeters.

Greig, J. (2021), The First Principle in Late Neoplatonism: A Study of the One's Causality in Proclus and Damascius, Leiden, Brill.

Helmig, C. (2006), "Die atmende Form in der Materie-Einige Überlegungen zum हैvv-

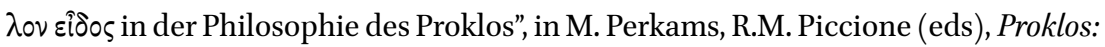
Methode, Seelenlehre, Metaphysik, Leiden, Brill, p. 259-278.

Helmig, C. (2012), Forms and Concepts: Concept Formation in the Platonic Tradition, Berlin, De Gruyter.

Jones, J.D. (2005), "An Absolutely Simple God? Frameworks for Reading PseudoDionysius Areopagite", in The Thomist 69/3, p. 371-406.

Kappes, C.W., Goff, J.I., Giltner, T.A. (2014), "Palamas Among the Scholastics: A Review Essay Discussing D. Bradshaw, C. Athanasopoulos, C. Schneider et al., Divine Essence and Divine Energies: Ecumenical Reflections on the Presence of God in Eastern Orthodoxy (Cambridge: James and Clarke, 2013)", in Logos: A Journal of Eastern Christian Studies 55, p. 175-220.

Karamanolis, G. (2009), "Plotinus on Quality and Immanent Form”, in R. Chiaradonna, F. Trabattoni (eds), Physics and Philosophy of Nature in Greek Neoplatonism: Proceedings of the European Science Foundation Exploratory Workshop (Il Ciocco, Castelvecchio Pascoli, June 22-24, 2006), Leiden, Brill, p. 79-10o.

Lauritzen, F. (2012), "Pagan Energies in Maximus the Confessor: The Influence of Proclus on Ad Thomam 5", in Greek, Roman, and Byzantine Studies 52, p. 226-239.

Lilla, S. (1990), "Die Lehre von den Ideen als Gedanken Gottes im griechischen patristischen Denken", in H. Eisenberger (ed.), EPMHNEYMATA: Festschrift für Hadwig Hörner zum 6o. Geburtstag, Heidelberg, Carl Winter, p. 27-50.

Lilla, S. (1997), "Pseudo-Denys L'Aréopagite, Porphyre et Damascius", in Y. De Andia (ed.), Denys l'Aréopagite et sa postérité en Orient et en Occident: Actes du colloque international, Paris, 21-24 Septembre 1994, Collection des études augustiniennes, Paris, Institut d'études augustiniennes, p. 117-152.

Lloyd, A.C. (1976), “The Principle That the Cause Is Greater Than Its Effect”, in Phronesis $21 / 2$, p. $146-156$.

Long, A., Sedley, D. (1987), The Hellenistic Philosophers: Volume 1, Translations of the Prin- 
cipal Sources, with Philosophical Commentary, Vol. 1, Cambridge, Cambridge University Press.

Lossky, V. (1957), The Mystical Theology of the Eastern Church, London, James Clarke \& Co Ltd.

Louth, A. (1996), Maximus the Confessor, London / New York, Routledge.

Louth, A. (2008a), "The Reception of Dionysius up to Maximus the Confessor", in Modern Theology 24, p. 573-583.

Louth, A. (2008b), "The Reception of Dionysius in the Byzantine World", in Modern Theology 24, p. 585-599.

Louth, A. (2017), "Platonism from Maximos the Confessor to the Palaiologan Period", in A. Kaldellis, N. Siniossoglou (eds), The Cambridge Intellectual History of Byzantium, Cambridge, Cambridge University Press, p. 325-340.

Martijn, M. (2010), Proclus on Nature, Leiden, Brill.

Mueller-Jourdan, P. (2005), Typologie spatio-temporelle de l'ecclesia byzantine. La Mystagogie de Maxime le Confesseur dans la culture philosophique de l'Antiquité tardive, Leiden, Brill.

Mueller-Jourdan, P. (2015a), "The Foundation of Origenist Metaphysics", in P. Allen, B. Neil (eds), The Oxford Handbook of Maximus the Confessor, Oxford, Oxford University Press, p. 150-162.

Mueller-Jourdan, P. (2015b), "The Metaphysical Position of the Divine as "Desirable" in Proclus' Platonic Theology and Maximus Confessor's Thought”, in A. Levy, P. Annala, O. Hallamaa, T. Lankila (eds), The Architecture of the Cosmos. St Maximus the Confessor. New Perspectives, Helsinki, Luther-Agricola-Society, p. 141-152.

Perl, E. (2010), "Pseudo-Dionysius the Areopagite", in L.P. Gerson (ed.), Cambridge History of Philosophy in Late Antiquity, Cambridge, Cambridge University Press, p. 767787 .

Petroff, V. (2015), "Y $₹ \alpha \dot{\rho} \chi \omega$ and $v \varphi i \sigma \tau \eta \mu \iota$ in Maximus the Confessor's Ambigua", in A. Levy, P. Annala, O. Hallamaa, T. Lankila (eds), The Architecture of the Cosmos. St Maximus the Confessor. New Perspectives, Helsinki, Luther-Agricola-Society, p. 93120.

Riggs, T. (2010), "Erôs, the Son, and the Gods as Metaphysical Principles in Proclus and Dionysius", in Dionysius 28, p. 97-130.

Riggs, T. (2011), "How to Speak of the Trinity: Henadology, Dionysius and Modern Commentary”, in Quaestiones Disputatae 2/1/2, p. 70-82.

Sharples, R.W. (1982), "Alexander of Aphrodisias on Divine Providence: Two Problems", in Classical Quarterly 32/1, p. 198-211.

Shchukin, T. (2017), "Matter as a Universal: John Philoponus and Maximus the Confessor on the Eternity of the World", in Scrinium 13, p. 361-382.

Sherwood, P. (1955), The Earlier 'Ambigua' of Saint Maximus the Confessor and His Refutation of Origenism, Rome, Orbis Catholicus, Herder. 
Sorabji, R. (1983), Time, Creation, and the Continuum: Theories in Antiquity and the Early Middle Ages, London, Duckworth.

Sorabji, R. (2016), "Dating of Philoponus' Commentaries on Aristotle and of His Divergence from His Teacher Ammonius", in R. Sorabji (ed.), Aristotle Re-Interpreted: New Findings on Seven Hundred Years of the Ancient Commentators. Ancient Commentators on Aristotle, London / New York, Bloomsbury, p. 367-392.

Steel, C. (1978), The Changing Self: A Study on the Soul in Later Neoplatonism:Iamblichus, Damascius and Priscianus, Brussels, Paleis der Academiën.

Steel, C. (1997), "Breathing Thought: Proclus on the Innate Knowledge of the Soul", in J.J. Cleary (ed.), The Perennial Tradition of Neoplatonism, Leuven, Leuven University Press, p. 293-307.

Steel, C. (2002), "Neoplatonic Versus Stoic Causality: The Case of the Sustaining Cause ('sunektikon')", in Quaestio 2/1, p. 77-96.

Steel, C. (2012), "Maximus Confessor on Theory and Praxis: A Commentary on Ambigua ad Johannem Vi (10) 1-19", in T. Bénatouil, M. Bonazzi (eds), Theoria, Praxis, and the Contemplative Life After Plato and Aristotle, Leiden / Boston, Brill, p. 229-257.

Steel, C. (2014), "Maximus Confessor and John Scotus Eriugena on Place and Time", in W. Otten, M.I. Allen (eds), Eriugena and Creation: Proceedings of the Eleventh International Conference on Eriugenian Studies, Held in Honor of Edouard Jeauneau, Chicago, 9-12 November 2011, Turnhout, Brepols, p. 291-318.

Steel, C., Bart, J., Van Deun, P. (2018), "Maximus der Bekenner”, in C. Riedweg, C. Horn, D. Wyrwa (eds), Die Philosophie der Antike 5/3: Philosophie der Kaiserzeit und der Spätantike, Grundriss der Geschichte der Philosophie, Basel, Schwabe, p. 22682287.

Tollefsen, T.T. (2012), Activity and Participation in Late Antique and Early Christian Thought, Oxford, Oxford University Press.

Van Riel, G. (2010), “Damascius”, in L. Gerson (ed.), The Cambridge History of Philosophy in Late Antiquity, Cambridge, Cambridge University Press, p. 667-696.

Varlamova, M. (2017), “Philoponus' Dispute Against the Eternity of the World and Its Influence on the Byzantine Philosophy", in Scrinium 13, p. 383-399.

Verrycken, K. (1990), “The Development of Philoponus' Thought and Its Chronology”, in R. Sorabji (ed.), Aristotle Transformed: The Ancient Commentators and Their Influence, Ithaca, NY, Cornell University Press, p. 233-274.

Verrycken, K. (2010), "John Philoponus", in L. Gerson (ed.), The Cambridge History of Philosophy in Late Antiquity, Cambridge, Cambridge University Press, p. 733-755.

Wear, S.K., Dillon, J.M. (2007), Dionysius the Areopagite and the Neoplatonist Tradition. Aldershot, Burlington, Ashgate Publishing, Ltd.

Wood, J.D. (2018), "Creation Is Incarnation: The Metaphysical Peculiarity of the Logoi in Maximus Confessor", in Modern Theology 34/1, p. 82-102. 